
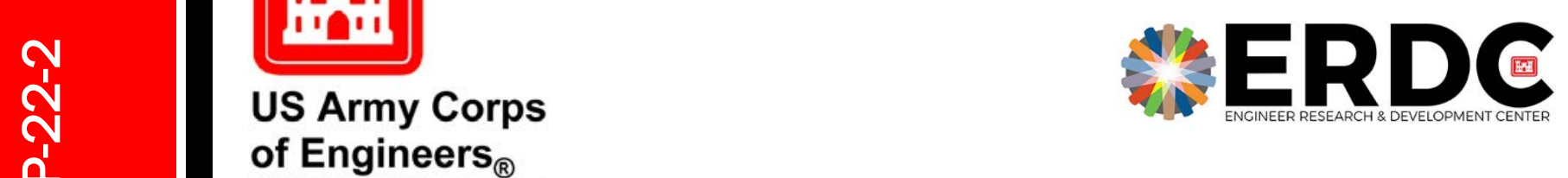
Engineer Research and Development Center

\title{
Environmental Impact of Metals Resulting from Military Training Activities
}

\section{A Review}

Amanda J. Barker, Jay L. Clausen, Thomas A. Douglas,

February 2022

Anthony J. Bednar, Christopher S. Griggs, William A. Martin 
The U.S. Army Engineer Research and Development Center (ERDC) solves the nation's toughest engineering and environmental challenges. ERDC develops innovative solutions in civil and military engineering, geospatial sciences, water resources, and environmental sciences for the Army, the Department of Defense, civilian agencies, and our nation's public good. Find out more at www.erdc.usace.army.mil.

To search for other technical reports published by ERDC, visit the ERDC online library at https://erdclibrary.on.worldcat.org/discovery. 


\title{
Environmental Impact of Metals Resulting from Military Training Activities
}

\author{
A Review \\ Amanda J. Barker, Jay L. Clausen, and Thomas A. Douglas \\ Cold Regions Research and Engineering Laboratory \\ U.S. Army Engineer Research and Development Center \\ Fort Wainwright, AK 9970372 Lyme Road, Hanover, NH 03755 \\ Anthony J. Bednar, Christopher S. Griggs, and William A. Martin \\ Environmental Laboratory \\ U.S. Army Engineer Research and Development Center \\ 3909 Halls Ferry Road \\ Vicksburg, MS 39180
}

Final report

Approved for public release; distribution is unlimited.

\author{
Prepared for National Guard Bureau \\ Camp Edwards, MA 02452 \\ Under MIPR 90353118
}




\section{Preface}

This study was conducted for the National Guard Bureau, Impact Area GW Study Office, Camp Edwards, MA under MIPR 90353118.

The work was performed by U.S. Army Engineer Research and Development Center, Cold Regions Research Engineering Laboratory (ERDCCRREL) and the Environmental Laboratory (ERDC-EL). At the time of publication of this paper, the deputy director for ERDC-CRREL was Mr. Bryan E. Baker and the director was Dr. Joseph Corriveau; the deputy director for ERDC-EL was Dr. Jack Davis and the Director was Dr. Edmund Russo.

This paper was originally published online in Chemosphere on 26 November 2020.

COL Teresa A. Schlosser was the commander of ERDC and the director was Dr. David W. Pittman.

DISCLAIMER: The contents of this report are not to be used for advertising, publication, or promotional purposes. Citation of trade names does not constitute an official endorsement or approval of the use of such commercial products. All product names and trademarks cited are the property of their respective owners. The findings of this report are not to be construed as an official Department of the Army position unless so designated by other authorized documents. 


\title{
Environmental impact of metals resulting from military training activities: A review
}

\begin{abstract}
A B S T R A C T
The deposition of metals into the environment as a result of military training activities remains a longterm concern for Defense organizations across the globe. Of particular concern for deposition and potential mobilization are antimony $(\mathrm{Sb})$, arsenic $(\mathrm{As})$, copper $(\mathrm{Cu})$, lead $(\mathrm{Pb})$, and tungsten $(\mathrm{W})$, which are the focus of this review article. The fate, transport, and mobilization of these metals are complicated and depend on a variety of environmental factors that are often convoluted, heterogeneous, and sitedependent. While there have been many studies investigating contaminant mobilization on military training lands there exists a lack of cohesiveness surrounding the current state of knowledge for these five metals. The focus of this review article is to compile the current knowledge of the fate, transport, and ultimate risks presented by metals associated with different military training activities particularly as a result of small arms training activities, artillery/mortar ranges, battleruns, rocket ranges, and grenade courts. From there, we discuss emerging research results and finish with suggestions of where future research efforts and training range designs could be focused toward further reducing the deposition, limiting the migration, and decreasing risks presented by metals in the environment. Additionally, information presented here may offer insights into $\mathrm{Sb}, \mathrm{As}, \mathrm{Cu}, \mathrm{Pb}$, and $\mathrm{W}$ in other environmental settings.
\end{abstract}

\section{Contents}

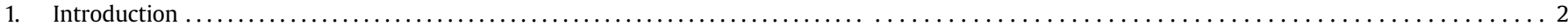

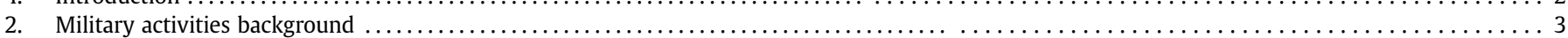

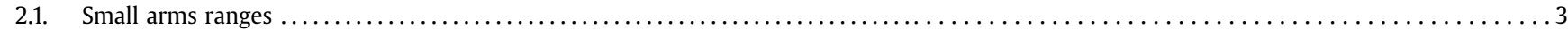

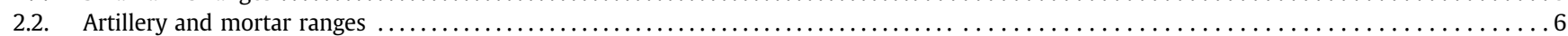

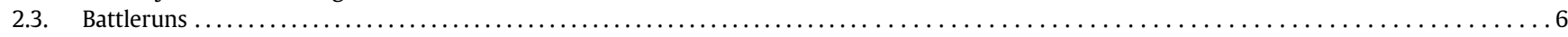

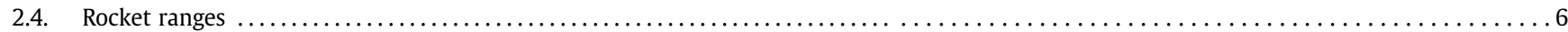

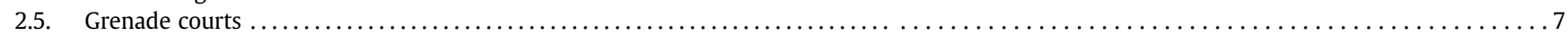




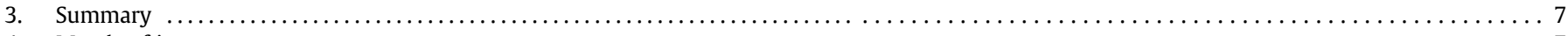

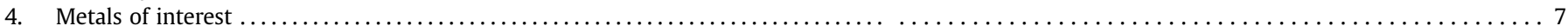

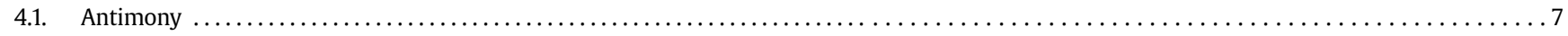

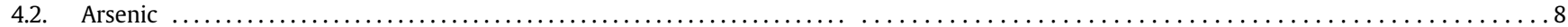

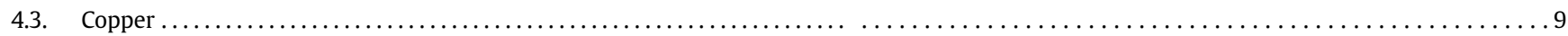

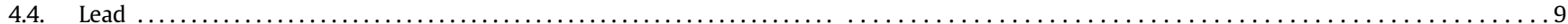

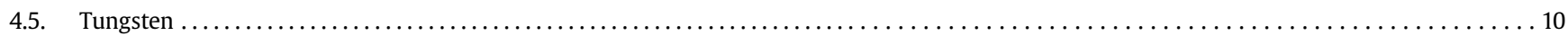

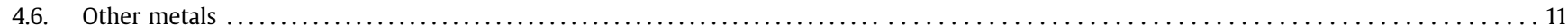

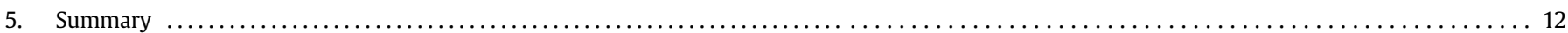

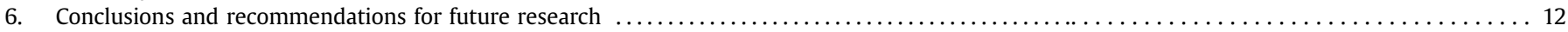

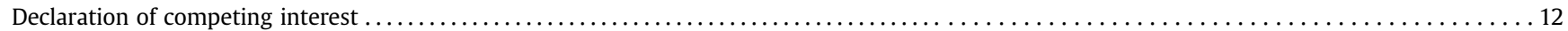

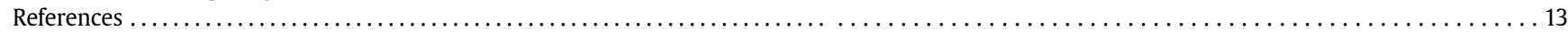

\section{Introduction}

Military training activities, particularly with small arms, mortars, artillery, and rockets, have the likelihood of depositing metals to target berm and impact area soils, accounting for an estimated60,100 metric tonnes of $\mathrm{Pb}$ used in the production of ammunition in the U.S. (USGS, 2013). There are an estimated 16,000 to 18,000 firing ranges that exist in the U.S. both military and nonmilitary (Laidlaw et al., 2017) and in Europe there is are 'tens of thousands' of tonnes of $\mathrm{Pb}$ ammunition released into the environment annually (Pain et al., 2019). The ultimate fate of metals in soils and groundwater on military lands provides a long-term risk for Defense Departments worldwide. While shooting ranges designated for military practice are often the focus for long-term health studies, public shooting ranges are also a source of small arms projectiles in the environment, with both types of facilities accounting for an estimated 16,000 to 18,000 firing ranges in the U.S. alone (Laidlaw et al., 2017). The particular challenge is that each metal has the potential to behave differently in the environment with varying solubility, surface charge, and affinity for select geomedia. This translates to complicated site-specific fate and transport processes that may be difficult to interpret and model on a broader scale or as a function of unique geomedia characteristics (e.g., soil, surface water, and groundwater). Lead ( $\mathrm{Pb})$, antimony $(\mathrm{Sb})$, copper $(\mathrm{Cu})$, arsenic $(\mathrm{As})$, zinc $(\mathrm{Zn})$, and more recently, tungsten $(\mathrm{W})$, are the predominant metals associated with bullets and as a result are often the leading risks to public health and environmental safety for off-site migration.

Numerous studies have focused on metal concentrations and transport due to training activities that can be generally divided into eight main categories: (1) capturing a snapshot of the pointsource contamination (Murray et al., 1997; Basunia and Landsberger, 2001; Clausen et al., 2007a; Clausen and Korte, 2009a), (2) mobility-focused (Johnson et al., 2005; Strømseng et al., 2009; Clausen and Korte, 2009b; Yin et al., 2010; Clausen et al., 2011b; Klitzke et al., 2012; Martin et al., 2014), (3) laboratory-based studies usually concerning toxicity, mobilization, redox processes, sorption, and/or reaction kinetics (Belzile et al., 2001; Rooney et al., 2007; Mitsunobu et al., 2010; Ilgen et al., 2014), (4) speciation characterization (Cao et al., 2003; Hardison et al., 2004; Vantelon et al., 2005; Scheinost et al., 2006; Bednar et al., 2007; Ackermann et al., 2009; Griggs et al., 2010a; Clausen et al., 2010a; Rubio et al., 2017; Bostick et al., 2018; Barker et al., 2020), (5) remediation studies (Jardine et al., 2007; Labare et al., 2004; Migliorini et al., 2004; Griggs et al., 2011; Sanderson et al., 2015; Ogawa et al., 2015, 2016; Lewińska and Karczewska, 2019; Barker et al., 2019b; Larson et al., 2007a), (6) animal toxicity (Braun et al., 1997; Dvorak et al., 2020), (7) microbial/plant impacts (Rooney et al., 1999; Labare et al., 2004; Migliorini et al., 2004;
Robinson et al., 2008; Pourrut et al., 2011; Evangelou et al., 2012; Busby et al., 2019), or (8) large-scale, comprehensive approach highlighting multiple categories, such as laboratory-based remediation trials (Okkenhaug et al., 2016; Larson et al., 2007b) or fieldscale speciation characterization coupled with remediation efforts (Barker et al., 2019a; Larson et al., 2016).

Military shooting ranges tend to be complicated systems to study, primarily as a result of the many types of activities that can occur and the multitude of metals present. Additionally, environmental conditions, such as the soil $\mathrm{pH}, \mathrm{Eh}$, and speciation that may favor sorption (i.e. local retention) or desorption of a given species to soils may provide conditions that promote mobility (i.e. potential off site migration) for other species, particularly for cation metals (Pb) versus oxyanion metalloids (Sb) (Jardine et al., 2007; Okkenhaug et al., 2011, 2016; Ogawa et al., 2015; Doherty et al., 2017; Barker et al., 2019a). Since military training activities occur all over the world and during all seasons there is a wide range in environmental and biogeochemical conditions and processes that govern the ultimate fate of metals in training range soils and waters. This provides a major challenge in our ability to transfer results from one metal or one location to others.

Since access to literature studies specifically on military ranges can be limited much of the research results on metal deposition and fate from small arms fire has come from the study of public sport ranges (Roscoe et al., 1989; Stansley et al., 1992; Mellor and McCartney, 1994; Bruell et al., 1999; Craig et al., 2002; Soeder and Miller, 2003; Sorvari et al., 2006; Duggan and Dhawan, 2007), which are included in this review. Public sport ranges are widely distributed across the globe and provide a venue to study a variety of projectiles that include some similar to military weapons, particularly the 5.56, 7.62, and $9 \mathrm{~mm}$ rounds. Additionally, studies of older ranges can provide limited historical information about what type of bullets were fired there, so information on whether it was a small arms range or a larger detonation area can be lacking.

As is the case for most investigations of the deposition and fate of metals in the environment the speciation (oxidation state and local structure) largely controls mobility, fate and transport, sorption-desorption processes, toxicity, and solubility in soil porewaters, surface waters, and groundwater (Wilson et al., 2010; Ilgen et al., 2014). Recent and emerging advances in microanalytical techniques, particularly surface interrogations at the sub-micron scale using X-ray fluorescence (XRF), absorption, and scattering techniques, has provided a greater understanding of the rate and distance into weathering bullet material that metal speciation changes (Vantelon et al., 2005; Scheinost et al., 2006; Ackermann et al., 2009; Rubio et al., 2017; Bostick et al., 2018; Qui et al., 2018a, 2018b; Barker et al., 2019a, 2020).

This review is focused on synthesizing the current knowledge of the fate, transport, and ultimate risks presented by metals 
associated with military training activities. Our main focus will be on understanding and identifying trends in literature for metal mobilization, transport, speciation, and ultimate fate of metals present at shooting ranges. We primarily focus on abiotic interactions and to a lesser extent biotic transformation, plant uptake, or animal toxicity. Additionally, there are numerous organic contaminants derived from munitions training, but our focus for this review is specifically metals and metalloids. First, we present an introduction of common training range uses/types and then identify the most likely metals of concern at each and risk for military training range managers. The primary focus of this review is on metals derived from small-arms range bullets as the most likely source of contamination from military (and civilian) training (As, $\mathrm{Sb}, \mathrm{Cu}, \mathrm{Pb}, \mathrm{W}$ ). Zinc is mentioned as a component of bullets and is typically present in relatively small concentrations on shooting ranges. However, we do not present detailed information on $\mathrm{Zn}$ here as the majority of studies do not report a high enough load of $\mathrm{Zn}$ to present significant health concerns compared to the other metals. The review concludes with a discussion of emerging research and suggestions of where future research efforts and training range designs should focus toward further limiting the deposition and ultimate risks presented by metals in the environment. Though not a focus of this review the authors suggest results of metal-soil and metal-water interactions from training activities can provide information to assist remediation activities at other locations where metals are present in the environment either naturally or from human activities like mining, industrial activities, or waste disposal.

\section{Military activities background}

\subsection{Small arms ranges}

Military projectiles typically consist of a steel penetrator followed by a $\mathrm{Pb} / \mathrm{Sb}$ slug jacketed with an alloy of $\mathrm{Cu}, \mathrm{Zn}$, and $\mathrm{Pb}$, although not all small arms projectiles have a $\mathrm{Cu}$ alloy jacket (Barker et al., 2020), such as some handgun and shotgun cartridges, which contain bare slugs, balls, or pellets (ITRC, 2003). Fig. 1 is an example of a typical small-arms projectile. In this example, Fig. 1 shows the cartridge and the $5.56-\mathrm{mm}$ projectiles used in the $\mathrm{M}-16$ rifle. The brass cartridge contains the projectile, propellant, and ignition cap. The ignition cap may contain compounds of Sb, barium (Ba), $\mathrm{Pb}$ as $\mathrm{Pb}$ styphnate, and potassium (K). Tracers contain compounds of $\mathrm{Ba}$, magnesium (Mg), $\mathrm{K}$, strontium (Sr), and $\mathrm{Zn}$. Arsenic (As) is used as hardening agent in steel shot associated with shotgun use and as a contaminant in $\mathrm{Pb}$ alloys where $\mathrm{Sb}$ is present as a hardening agent.
Copper makes up the majority of the mass of a typical projectile followed by $\mathrm{Pb}, \mathrm{Zn}$, iron (Fe) in the form of steel, and Sb. Antimony typically comprises anywhere between 0.7 and 10 percent by weight of the $\mathrm{Pb}$ penetrator (Randich et al., 2002; Johnson et al., 2005; Ackermann et al., 2009; Laporte-Saumure et al., 2011). For a short period in the early 2000's the U.S. Army developed a projectile where the $\mathrm{Pb}$ penetrator was replaced with a $\mathrm{W} /$ nylon material (Clausen et al., 2007b). This projectile was phased out in the late 2000's due to performance and environmental concerns related to W fate-and-transport (Dermatas et al., 2004; Bednar et al., 2008; O'Connor et al., 2009a,b; Bostick et al., 2018). More recently, the U.S. Army is beginning to phase in a new small-arms projectile composed of a Cu penetrator (Laidlaw et al., 2017).

The majority of military training impact studies focus on small arms ranges (SARs), particularly studies concerning metals. Table 1 compiles metal concentrations from literature as a function of available environmental data and known site information. The heavy focus on studying SARs is likely due to having a highly localized anthropogenic source of metals in a relatively small impact area (Fig. 2). Also, they are common throughout most military organizations in the world. The majority of recent and heavily cited SAR studies that were the focus of this review on SARs capture $\mathrm{Pb}, \mathrm{Sb}$, and $\mathrm{Cu}$ concentrations (Table 1) from U.S., Norway, Switzerland, and Australia ranges, both public and for military-use only. Zinc and As are reported to a lesser extent and are also often reported with Nickel (Ni) (impurity in the copper casing) and chromium (Cr) (impurity in the steel). Tungsten was a heavy focus in the 2007 to 2012 timeframe for certain sites that specifically employed the 'green' $\mathrm{Pb}$ alternative for military bullets (Clausen and Korte, 2009a). For the most part, $\mathrm{Pb}$ is the most heavily studied bullet material, followed by $\mathrm{Sb}$ and $\mathrm{Cu}$ (Table 1 ).

Environmental site data tends to be lacking when comparing between publications because some authors present detailed background site data and environmental characteristics and some only present total concentrations and $\mathrm{pH}$ data. Few publications present approximate deposition loads in relation to range operation time, possibly because those records are difficult to ascertain. Ackermann et al. (2009), which also focused on ranges studied by Scheinost et al. (2006), presented detailed estimates of bullet loadings for two Swiss ranges, but did not have accompanying total soil concentrations for metals and instead focused on detailed speciation of Sb. Wynter et al. (2012) documented the $5.56 \mathrm{~mm}$ and $7.62 \mathrm{~mm}$ bullet loading of three berms averaging 2200 and 6233 bullets per berm, respectively, and documented the $\mathrm{pH}$ and concentration of metals in the berm soil, runoff and leachate waters. In a more recent study, Barker et al. (2019a) fired a controlled amount of bullets into test berms and reported loading values of 2000

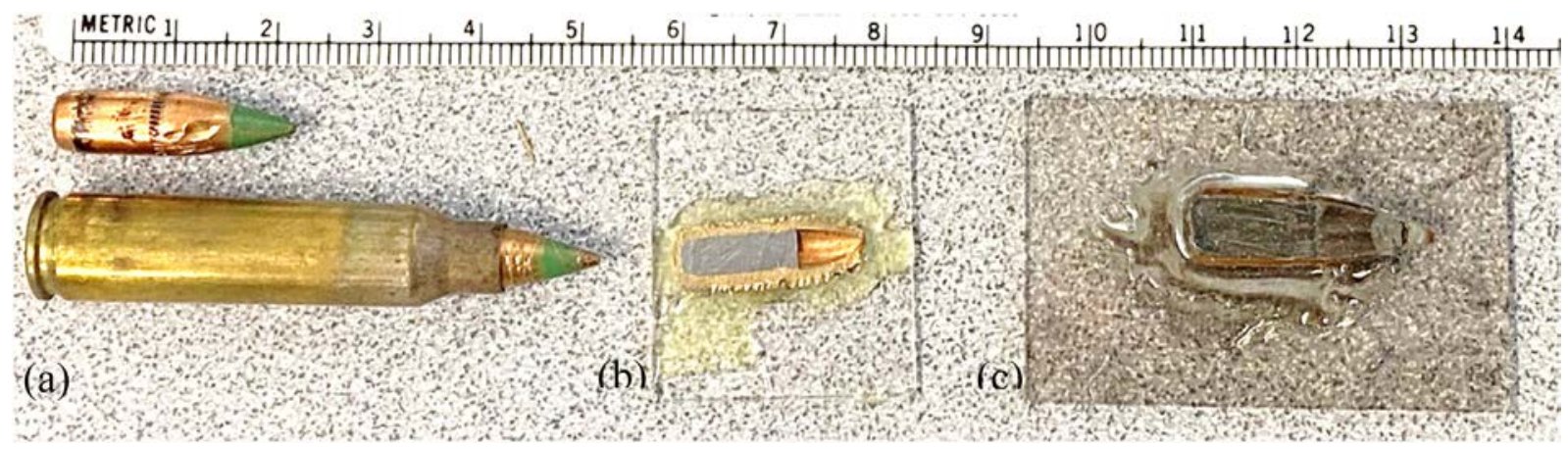

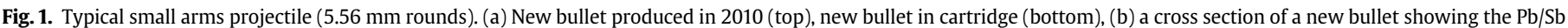

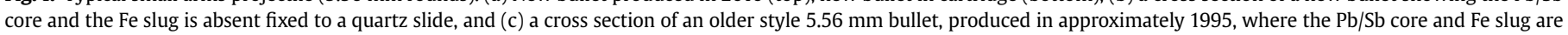
encased in copper and also a steel jacket, which is not present on the more recent style of 5.56 mm rounds fixed to a quartz slide. (Photos by A.J. Barker). 
Table 1

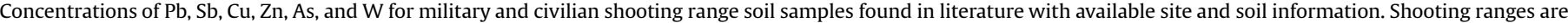
designated as military or public within the table.

\begin{tabular}{|c|c|c|c|c|c|c|c|c|c|c|c|c|c|c|c|c|c|}
\hline Study Area & Berm material & Operation & \multicolumn{2}{|c|}{ Sample Type } & $\mathrm{pH}$ & \multicolumn{2}{|c|}{$\begin{array}{l}\mathrm{Pb}(\mathrm{mg} / \\
\mathrm{kg})\end{array}$} & \multicolumn{2}{|c|}{$\begin{array}{l}\mathrm{Sb}(\mathrm{mg} / \\
\mathrm{kg})\end{array}$} & \multicolumn{2}{|c|}{$\begin{array}{l}\mathrm{Cu}(\mathrm{mg} / \\
\mathrm{kg})\end{array}$} & \multicolumn{2}{|c|}{$\begin{array}{l}\mathrm{Zn}(\mathrm{mg} / \\
\mathrm{kg})\end{array}$} & \multicolumn{2}{|c|}{$\begin{array}{l}\text { As }(\mathrm{mg} / \\
\mathrm{kg})\end{array}$} & $\begin{array}{l}\mathrm{W}(\mathrm{mg} / \\
\mathrm{kg})\end{array}$ & Reference \\
\hline $\begin{array}{l}\text { Public rifle range, } \\
\text { Florida }\end{array}$ & Phosphatic clay soil & 3 years & \multicolumn{2}{|l|}{ Berm soil } & 5.76 & \multicolumn{2}{|c|}{12,710} & \multicolumn{2}{|l|}{-} & \multicolumn{2}{|l|}{-} & \multicolumn{2}{|l|}{-} & \multicolumn{2}{|l|}{-} & - & Cao et al. (2003) \\
\hline $\begin{array}{l}\text { Public rifle range, } \\
\text { Florida }\end{array}$ & Calcareous & 16 years & \multicolumn{2}{|l|}{ Berm soil } & 7.36 & \multicolumn{2}{|c|}{648,400} & \multicolumn{2}{|l|}{-} & \multicolumn{2}{|l|}{-} & \multicolumn{2}{|l|}{-} & \multicolumn{2}{|l|}{-} & - & Cao et al. (2003) \\
\hline $\begin{array}{l}\text { Pantex Firing Range, } \\
\text { Texas }\end{array}$ & - & - & $\begin{array}{l}\text { random soil } \\
\text { sampling }\end{array}$ & & - & $11-4$ & 675 & 1 to & 517 & $\begin{array}{l}13 \mathrm{t} \\
359\end{array}$ & & - & & - & & - & $\begin{array}{l}\text { Basunia and Landsberger } \\
\text { (2001) }\end{array}$ \\
\hline $\begin{array}{l}\text { Northwest SAR, } \\
\text { military }\end{array}$ & - & - & Berm-face s & soil ${ }^{\mathrm{a}}$ & - & 64,68 & & 105 & & 12,9 & & 124 & & 26 & & 1067 & $\begin{array}{l}\text { Clausen and Korte } \\
\text { (2009a) }\end{array}$ \\
\hline Southeast SAR, military & - & - & Berm-face $s$ & soil ${ }^{a}$ & - & 7794 & & 112 & & 195 & & 217 & & $<10$ & & 108 & $\begin{array}{l}\text { Clausen and Korte } \\
\text { (2009a) }\end{array}$ \\
\hline Northeast SAR, military & - & - & Berm-face $s$ & soil ${ }^{\mathrm{a}}$ & - & 395 & & 12 & & 470 & & 38 & & 1.8 & & 612 & $\begin{array}{l}\text { Clausen and Korte } \\
\text { (2009a) }\end{array}$ \\
\hline $\begin{array}{l}\text { Public pistol range, } \\
\text { Florida }\end{array}$ & $\begin{array}{l}\text { sand, sparse } \\
\text { vegetation }\end{array}$ & 3 months & Berm soil & & - & $193^{b}$ & & - & & - & & - & & - & & - & Hardison et al. (2004) \\
\hline $\begin{array}{l}\text { Public rifle range, } \\
\text { Florida }\end{array}$ & $\begin{array}{l}\text { sand, sparse } \\
\text { vegetation }\end{array}$ & 3 months & Berm soil & & - & 1,142 & & - & & - & & - & & - & & - & Hardison et al. (2004) \\
\hline $\begin{array}{l}\text { Public range, } \\
\text { Switzerland }\end{array}$ & clay/loam texture & 90 years & $\begin{array}{l}\text { Surface, } 2 \mathrm{n} \\
\text { target }\end{array}$ & from & 7.0 & 23,62 & & 110 & & 895 & & 585 & & - & & - & Vantelon et al. (2005) \\
\hline Quartino, Swiss range & $\begin{array}{l}72 \mathrm{~g} / \mathrm{kg} \text { organic } \\
\text { carbon }\end{array}$ & - & Berm soil, 0 & $-5 \mathrm{~cm}$ & 9.4 & $>500$ &, 000 & 17,5 & & 445 & & - & & - & & - & Scheinost et al. (2006) \\
\hline Davos, Swiss range & $\begin{array}{l}6 \mathrm{~g} / \mathrm{kg} \text { organic } \\
\text { carbon }\end{array}$ & - & Berm soil, 0 & $-5 \mathrm{~cm}$ & 7.8 & 35,00 & & 190 & & 920 & & - & & - & & - & Scheinost et al. (2006) \\
\hline Goldau, Swiss range & $\begin{array}{l}29 \mathrm{~g} / \mathrm{kg} \text { organic } \\
\text { carbon }\end{array}$ & - & Berm soil, 0 & $-5 \mathrm{~cm}$ & 8.2 & 111,0 & 000 & 600 & & 305 & & - & & - & & - & Scheinost et al. (2006) \\
\hline Oberuzwil, Swiss range & $\begin{array}{l}300 \mathrm{~g} / \mathrm{kg} \text { organic } \\
\text { carbon }\end{array}$ & - & Berm soil, 0 & $-5 \mathrm{~cm}$ & 6.9 & 171,0 & 000 & 800 & & 272 & & - & & - & & - & Scheinost et al. (2006) \\
\hline Losone, Swiss range & $\begin{array}{l}330 \mathrm{~g} / \mathrm{kg} \text { organic } \\
\text { carbon }\end{array}$ & since 1960 & Behind berr & $\mathrm{n}, 1 \mathrm{~cm}$ & 3.2 & 80,90 & & 400 & & 189 & & - & & - & & - & Scheinost et al. (2006) \\
\hline Zuchwil, Swiss range & $\begin{array}{l}50 \mathrm{~g} / \mathrm{kg} \text { organic } \\
\text { carbon }\end{array}$ & - & $\begin{array}{l}\text { Behind berr } \\
-5 \mathrm{~cm}\end{array}$ & $\mathrm{n}, 0$ & 5.8 & 21,00 & & 160 & & 275 & & - & & - & & - & Scheinost et al. (2006) \\
\hline $\begin{array}{l}\text { Evjemoem, Norway } \\
\text { range }\end{array}$ & Silty sand & - & - & & 7.4 & 8700 & & 105 & & 135 & & - & & - & & - & Okkenhaug et al. (2013) \\
\hline Rena, Norway range & Silty sand & - & - & & 7.6 & 30,00 & & 290 & & 230 & & - & & - & & - & Okkenhaug et al. (2013) \\
\hline $\begin{array}{l}\text { Sessvollmoen, Norway } \\
\text { range }\end{array}$ & Silty sand & - & - & & 7.2 & 2200 & & 240 & & 350 & & - & & - & & - & Okkenhaug et al. (2013) \\
\hline $\begin{array}{l}\text { Steinsjøen, Norway } \\
\text { range }\end{array}$ & Silty sand & - & - & & 5.8 & 2050 & & 123 & & 145 & & - & & - & & - & Okkenhaug et al. (2013) \\
\hline Ulven, Norway range & Silty sand & - & - & & 8.8 & 2000 & & 260 & & 148 & & - & & - & & - & Okkenhaug et al. (2013) \\
\hline $\begin{array}{l}\text { Murray Bridge, } \\
\text { Australia }\end{array}$ & Primarily fine sand & 1970 & $\begin{array}{l}<2 \mathrm{~mm}, 0- \\
\text { berm }\end{array}$ & $10 \mathrm{~cm}$ & 9.29 & 12,16 & & 325 & & 355 & & 735 & & 8.83 & & - & $\begin{array}{l}\text { Sanderson et al., 2012; } \\
2015\end{array}$ \\
\hline Townsville, Australia & Primarily sand & 1960 & $\begin{array}{l}<2 \mathrm{~mm}, 0- \\
\text { berm }\end{array}$ & $10 \mathrm{~cm}$ & 6.39 & 955 & & 15.4 & & 362 & & 83.4 & & 1.16 & & - & $\begin{array}{l}\text { Sanderson et al., 2012; } \\
2015\end{array}$ \\
\hline Darwin, Australia & Primarily fine sand & - & $\begin{array}{l}<2 \mathrm{~mm}, 0- \\
\text { berm }\end{array}$ & $10 \mathrm{~cm}$ & 5.43 & 743 & & 9.45 & & 74.9 & & 29.3 & & 1.95 & & - & $\begin{array}{l}\text { Sanderson et al., 2012; } \\
2015\end{array}$ \\
\hline Perth, Australia & Primarily fine sand & - & $\begin{array}{l}<2 \mathrm{~mm}, 0- \\
\text { berm }\end{array}$ & $10 \mathrm{~cm}$ & 5.95 & 233 & & 7.40 & & 27.4 & & 16.7 & & 3.97 & & - & $\begin{array}{l}\text { Sanderson et al., 2012; } \\
2015\end{array}$ \\
\hline $\begin{array}{l}\text { Meadows Range, } \\
\text { Alaska }\end{array}$ & Silty loam & 20 years & Surface berı & m soil & 5.3 & 77.91 & & 8.43 & & 32.9 & & 66.1 & & 17.3 & & - & Barker et al. (2020) \\
\hline Test berms, Alaska & Sand & $\begin{array}{l}1 \text { firing } \\
\text { event }^{c}\end{array}$ & Surface berı & m soil & 8.38 & 16,41 & 13.3 & 275 & & 732 & & 172 & & d & & - & Barker et al. (2019a) \\
\hline Test berms, Alaska & Sandy loam & $\begin{array}{l}1 \text { firing } \\
\text { event }^{\mathrm{c}}\end{array}$ & Surface berı & m soil & 6.75 & 2808 & & 61.8 & & 214 & & 99.2 & & d & & - & Barker et al. (2019a) \\
\hline Test berms, Alaska & Loamy sand & $\begin{array}{l}1 \text { firing } \\
\text { event }^{\mathrm{c}}\end{array}$ & Surface berı & m soil & 5.66 & 1678 & & 32.5 & & 165 & & 94.8 & & 12.9 & & - & Barker et al. (2019a) \\
\hline Test berms, Alaska & Silty loam & $\begin{array}{l}1 \text { firing } \\
\text { event }^{\mathrm{c}}\end{array}$ & Surface berı & m soil & 5.34 & 458.8 & & 12.0 & & 62.8 & & 71.7 & & 14.5 & & - & Barker et al. (2019a) \\
\hline Fort Jackson, SC & Sandy silt w/gravel & - & Surface berı & n soil & - & 5924 & & 139 & & 310 & & 42.4 & & - & & - & Larson et al. (2016) \\
\hline $\begin{array}{l}\text { Joint Base Charleston, } \\
\text { NC }\end{array}$ & Washed sand & 14 months & Surface \& b & erm & 7.42 & 1814 & & 18.3 & & 102 & & 112 & & - & & - & Wynter et al. (2012) \\
\hline Study Area & Berm material & Operation & Sample Type & $\mathrm{pH}$ & $\begin{array}{l}\mathrm{Pb}( \\
\mathrm{kg})\end{array}$ & $(\mathrm{mg} /$ & $\begin{array}{l}\mathrm{Sb}( \\
\mathrm{kg})\end{array}$ & $(\mathrm{mg} /$ & $\begin{array}{l}\mathrm{Cu}( \\
\mathrm{kg})\end{array}$ & & $\begin{array}{l}\mathrm{Zn}( \\
\mathrm{kg})\end{array}$ & $(\mathrm{mg} /$ & $\begin{array}{l}\text { As (1 } \\
\mathrm{kg})\end{array}$ & & $\begin{array}{l}\mathrm{W}(\mathrm{n} \\
\mathrm{kg})\end{array}$ & Refe & rence \\
\hline Military range, Lithuania & a Alkaline soil & - & Berm soil & $\begin{array}{l}7.91 \\
-8.30\end{array}$ & 653 & $3.33^{b}$ & - & & 23.4 & & - & & - & & - & $\begin{array}{l}\text { Česy } \\
(201\end{array}$ & $\begin{array}{l}\text { naitè and Sujetoviené } \\
\text { 8) }\end{array}$ \\
\hline $\begin{array}{l}\text { Military range, NW } \\
\text { Spain }\end{array}$ & $\begin{array}{l}\text { Acidic, low clay } \\
\text { content }\end{array}$ & - & Berm soil & $\begin{array}{l}4.03 \\
-5.37\end{array}$ & 445 & $51.57^{b}$ & 96.1 & & 88.5 & & 31.6 & & 62.4 & & - & Rodı & íguez-Seijo et al. (2016) \\
\hline $\begin{array}{l}\text { Military range, South } \\
\text { Korea }\end{array}$ & Sandy loam & 20 years & Berm soil & 6.8 & 18,6 & 609 & 108 & & 562 & & 123 & & - & & - & & n et al. (2015) \\
\hline $\begin{array}{l}\text { Military range, South } \\
\text { Korea }\end{array}$ & Sandy loam & 30 years & Berm soil & 6.0 & 391 & & 26 & & 318 & & 104 & & - & & - & Islan & n et al. (2015) \\
\hline $\begin{array}{l}\text { Military range, } \\
\text { Botswana (TAB) }\end{array}$ & - & $\begin{array}{l}\text { since } \\
1995\end{array}$ & $\begin{array}{l}\text { Upper berm } \\
\text { soil }\end{array}$ & 8.6 & 38,3 & 386 & - & & 1,56 & & - & & - & & - & $\begin{array}{l}\text { Sehu } \\
\text { et al }\end{array}$ & $\begin{array}{l}\text { ibe et al., 2017; Dinake } \\
., 2018 \text { a }\end{array}$ \\
\hline
\end{tabular}


Table 1 (continued)

\begin{tabular}{|c|c|c|c|c|c|c|c|c|c|c|c|}
\hline Study Area & Berm material & Operation & Sample Typ & $\mathrm{pH}$ & $\begin{array}{l}\mathrm{Pb}(\mathrm{mg} / \\
\mathrm{kg})\end{array}$ & $\begin{array}{l}\mathrm{Sb}(\mathrm{mg} / \\
\mathrm{kg})\end{array}$ & $\begin{array}{l}\mathrm{Cu}(\mathrm{mg} / \\
\mathrm{kg})\end{array}$ & $\begin{array}{l}\mathrm{Zn}(\mathrm{mg} / \\
\mathrm{kg})\end{array}$ & $\begin{array}{l}\text { As (mg/ } \\
\mathrm{kg})\end{array}$ & $\begin{array}{l}\text { W (mg/ } \\
\mathrm{kg})\end{array}$ & Reference \\
\hline $\begin{array}{l}\text { Military range, NE } \\
\text { Poland }\end{array}$ & - & $\begin{array}{l}\text { Since } \\
1889\end{array}$ & $\begin{array}{l}0-20 \mathrm{~cm} \\
\text { depth }\end{array}$ & 7.67 & 3865 & - & 2541 & 8656 & - & - & Radziemska et al. (2019) \\
\hline Canadian SAR & $0.9 \%$ carbon & - & $\begin{array}{l}0-30 \mathrm{~cm} \\
\text { depth }\end{array}$ & 5.7 & 8550 & 370 & 904 & 169 & - & - & Guemiza et al. (2014) \\
\hline
\end{tabular}

-, indicates no information was provided.

a mean values were reported.

b only the highest concentrations were reported.

c $20005.56 \mathrm{~mm}$ bullets fired.

d below detection limit.

e values are approximate.

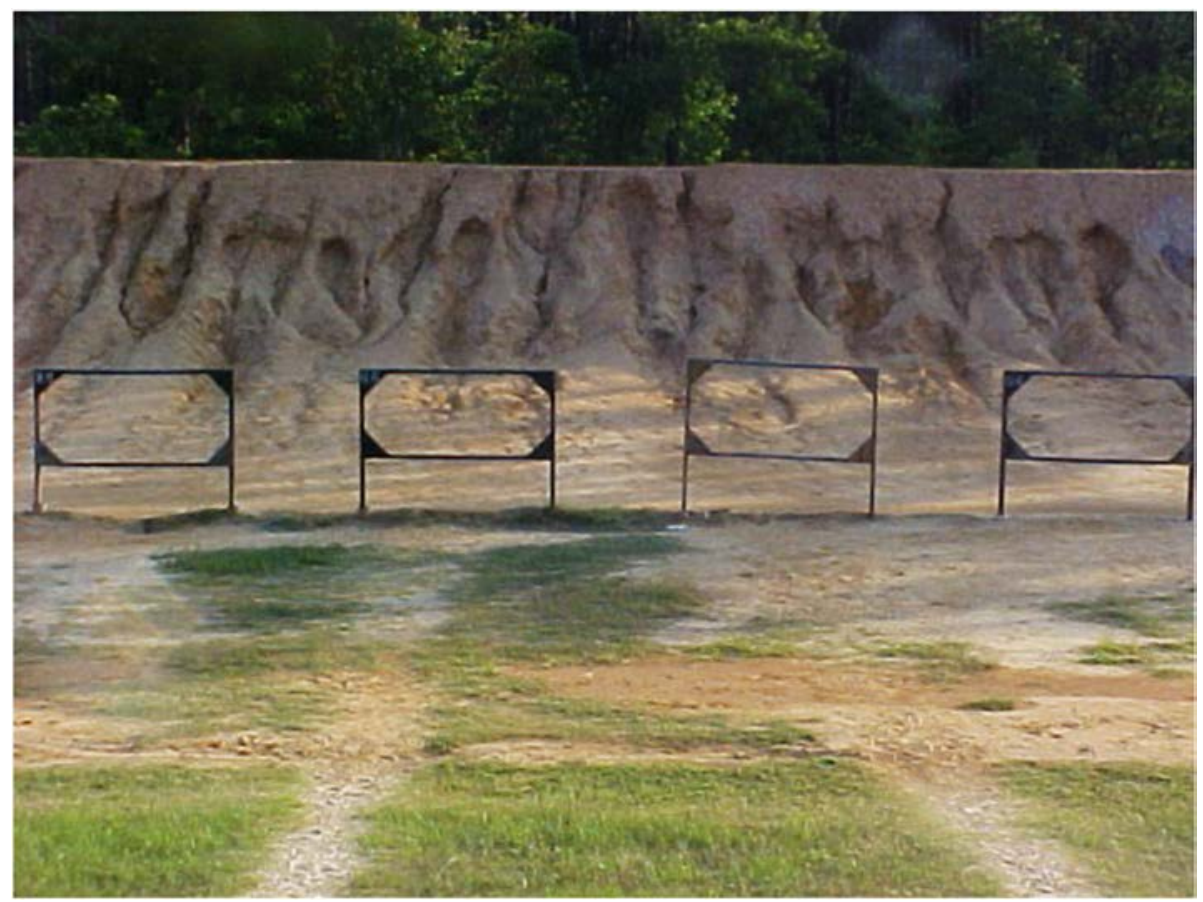

Fig. 2. Example of bullet pockets at a military small-arms range. (Photo by J.L. Clausen).

bullets per berm with a controlled amount of characterized soils.

In addition to loading amounts there also remains a lack of reporting critical information on soil characteristics like mineralogy and geochemistry. Soil information widely varies between publications. For example, Sanderson et al. (2012; 2015) report detailed soil information, including mineralogical data, soil texture percentages, and chemical parameters, whereas other publications present limited soil information and only the texture classification. For comparison purposes, the metal concentrations tend to be presented in terms of 'total metals'. However, some studies choose to sieve the soil to achieve the 'fine' fraction whereas others process the entire soil fractions for either digestion analysis or XRF analysis. Ideally, future publications on metals at SARs should focus on presenting as much detailed site information and history as possible, including at a minimum: site history (i.e., operation time, deposition loads), soil type (i.e., organic content, soil texture information), geochemical information (i.e., $\mathrm{pH}$, mineralogical phase assemblage, redox environment), and background values for both soil and aqueous samples.

Establishing background values for SARs is integral for understanding metal concentrations, particularly for contaminants that may be toxic, but present in lesser amounts than $\mathrm{Pb}, \mathrm{Sb}$, or $\mathrm{Cu}$, for example. Lead and $\mathrm{Cu}$, particularly, tend to be significantly above background concentrations in typical soils and crustal abundance sources. Arsenic and on some occasions Sb (Table 1) can be present at concentrations at or slightly above background concentrations, so establishing a baseline is important when determining if a site has a metal(loid) contamination issue or not. For example, the Northeast SAR in Clausen and Korte (2009a) has total Sb concentrations reported at $12 \mathrm{mg} / \mathrm{kg}$ and As at $1.8 \mathrm{mg} / \mathrm{kg}$. In some parts of the U.S. the background concentrations for As and $\mathrm{Sb}$ in soils are higher because of the native soils (like in Alaska; Barker et al., 2019a) and these levels of concentrations may be entirely reasonable to assume are within background range. However, in the Northeast U.S., As and Sb may be significantly higher than background and present more of a regulatory issue mandating clean-up of the site. While concentrations of Sb at $12 \mathrm{mg} / \mathrm{kg}$ and As at $1.8 \mathrm{mg} /$ $\mathrm{kg}$ may not seem like a cause for concern in the soil fractions for land managers the concentrations of $\mathrm{As}$ and $\mathrm{Sb}$ in the dissolved (or aqueous) fractions be concerning depending on the speciation and site conditions (i.e. historical addition of an amendment that can cause preferential leaching of certain metals) controlling release in soil solution and transport (Barker et al., 2019b). Therefore, presenting as much detailed information concerning background 
concentrations of the soils is important for comparing across different locations in the world and for management of SARs.

\subsection{Artillery and mortar ranges}

The military often trains with large caliber weapon systems consisting of mortars and artillery. The typical range configuration consists of firing points where the projectiles are launched and a target or impact area to where the projectiles are aimed. There are typically from hundreds of meters to tens of kilometers line distance between the firing point and the target. As such, it can be difficult to identify the exact location of every detonation and low order detonations of projectiles, research by VanDeMark et al. (2013) is using sensors to develop a solution to this problem. Most impact areas are several hundreds of thousands $\mathrm{m}^{2}$ to well over a million $\mathrm{m}^{2}$. The firing points are typically less than $40,000 \mathrm{~m}^{2}$ in size. Munitions fired in these areas commonly include but are not limited to 40-, 60-, and 81-mm mortars and 105- and 155-mm artillery projectiles (Fig. 3). Larger caliber projectiles such as mortars and artillery shells have casings largely composed of iron (Fe) and $\mathrm{Mn}$, greater than $95 \%$ by mass, with lesser amounts of other metals. Copper, $\mathrm{Zn}, \mathrm{Pb}$, and $\mathrm{Fe}$ are present in the rotating band and aluminum $(\mathrm{Al})$ is present in the fuse. These materials are present as solid metallic components. In some cases, instead of explosive filler in mortars and artillery the projectiles contain powdered metals such as $\mathrm{Ba}, \mathrm{Cu}, \mathrm{Mn}, \mathrm{K}, \mathrm{Sr}$, for pyrotechnic (e.g. flares, starbursts).

Extensive surface soil sampling, in excess of 1000 samples, was conducted in the artillery/mortar impact area of Joint Base Cape

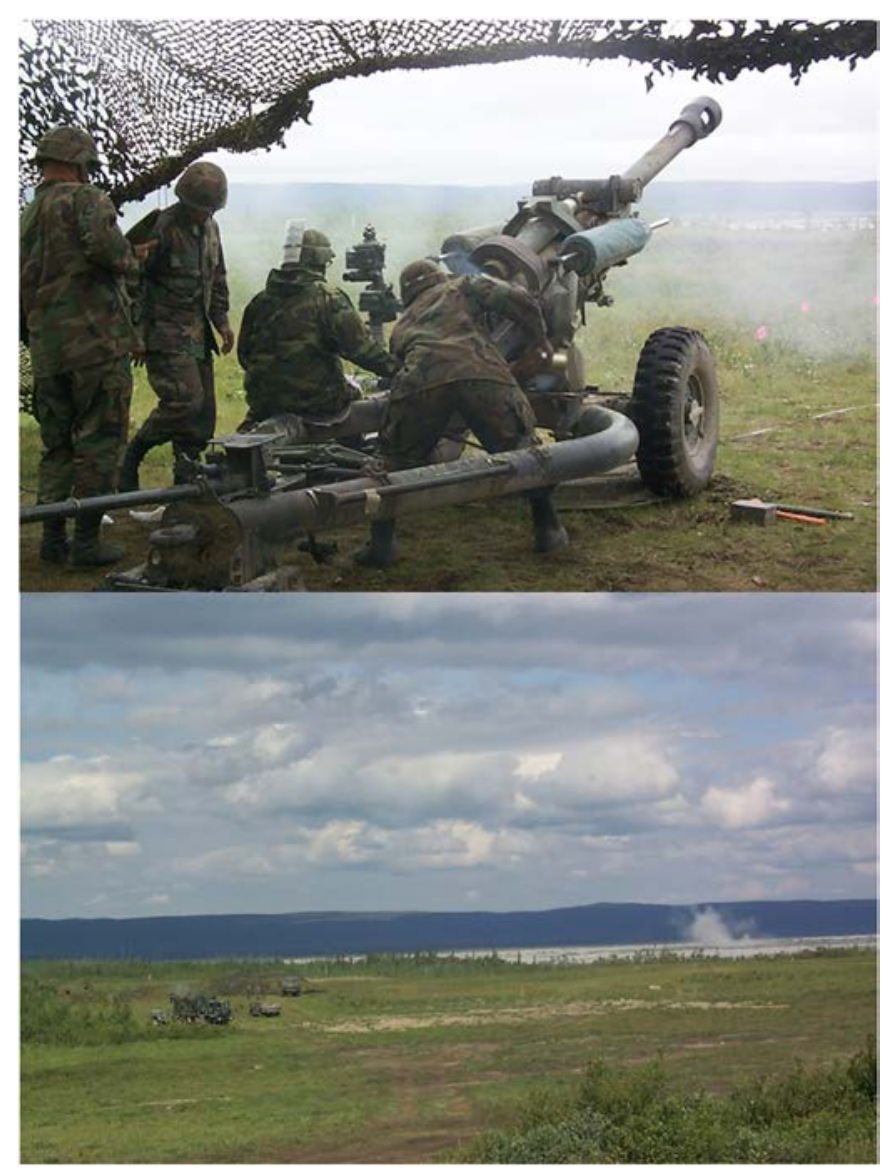

Fig. 3. Top: a $105 \mathrm{~mm}$ Howitzer firing point in action at Donnelly Training Area West, Alaska. Bottom: the $105 \mathrm{~mm}$ Howitzer firing point (lower left) and a projectile detonating at the impact area $5 \mathrm{~km}$ away (dust plume shown). (Photos by T.A. Douglas).
Cod for 29 metals. The results suggest there is some evidence for slightly elevated levels of $\mathrm{Al}, \mathrm{Mn}$, and $\mathrm{Ni}$ in surface soils although the reported values are within the background range developed for the site (AMEC, 2001b). There was no significant elevation of metal concentrations at the firing points. Spatial mapping of the metal results in surface soil from within the impact area did not suggest a relationship with known targets. Groundwater sampling did not reveal evidence of elevated metal levels. From this, Clausen et al. (2004) concluded there was little to no evidence of measurable environmental impacts resulting from the training with military munitions containing metal constituents. A study of groundwater at the Canadian Forces Base in Gagetown Brunswick yielded similar observations (Thiboutot et al., 2003b) although the authors felt Al was slightly elevated within the impact area as compared to background levels. Similarly, Sunahara et al. (2009) conducted a large survey of publications on artillery and mortar ranges at several installations and found that the large and sweeping landscapes translate to energetic compounds that are widely dispersed and present at low concentrations and the majority of these types of ranges that they found were largely uncontaminated.

It is worthy to note that there are reports of an artillery and mortar training range located on a salt marsh in Alaska (Eagle River Flats) that fired pyrotechnic devices containing white phosphorus that caused a significant environmental issue for feeding waterfowl (Racine et al., 1992). There are additional reports that study if low order detonations can contribute any metals on these types of ranges (Pennington et al., 2008). The authors found that in terms of metal input into the environment, there remains a limited number of extensive studies that pertain specifically to larger caliber artillery and mortar ranges in literature with the majority of studies focusing on energetic compounds from such activities (Brannon et al., 2000; Jenkins et al., 2001, 2006; Pennington et al., 2008; Thiboutot et al., 2012). More recently, Clausen et al. (2012) conducted a study of four Army pyrotechnic devices heavily used during range training to assess the metal deposition rate. The study concluded salts of $\mathrm{Ba}, \mathrm{Cu}, \mathrm{Mn}, \mathrm{K}$, and $\mathrm{Sr}$ were introduced into the environment. However, the sporadic and non-concentrated use preclude levels exceeding background concentrations. Consequently, the material presence of these elements in the natural environment under most situations does not allow differentiation with anthropogenic inputs.

\subsection{Battleruns}

Battleruns consist of ranges where mobile weapon systems are used, firing live ammunition from small-arms rounds up to tank rounds including missiles and rockets (Fig. 4). The metals present in these projectiles are similar to those previously discussed for smallarms and artillery/mortar projectiles. A characterization study by Thiboutot et al. (2001) at the Canadian Forces Base Shilo suggested the presence of $\mathrm{Ba}$, cadmium $(\mathrm{Cd}), \mathrm{Cu}, \mathrm{Sb}, \mathrm{Pb}$, thorium (Th), and $\mathrm{Zn}$ in surface soils above background levels but below regulatory action levels. The highest concentrations of these metals were observed around pop up targets. Biomass and groundwater samples did not indicate significant elevated levels of the above metals.

\subsection{Rocket ranges}

Anti-tank and anti-armor training occur on rocket ranges (Fig. 5). The primary casing material for these munitions is Al. Analysis of soil samples from two former rocket ranges at Joint Base Cape $\mathrm{Cod}$ revealed that the metals $\mathrm{Sb}, \mathrm{Cr}, \mathrm{Cu}, \mathrm{Pb}$, and $\mathrm{Zn}$ were elevated in surface soils immediately adjacent to targets as compared to background levels (Ogden 2000). However, the metals above are not present in the casing materials of anti-tank rockets 


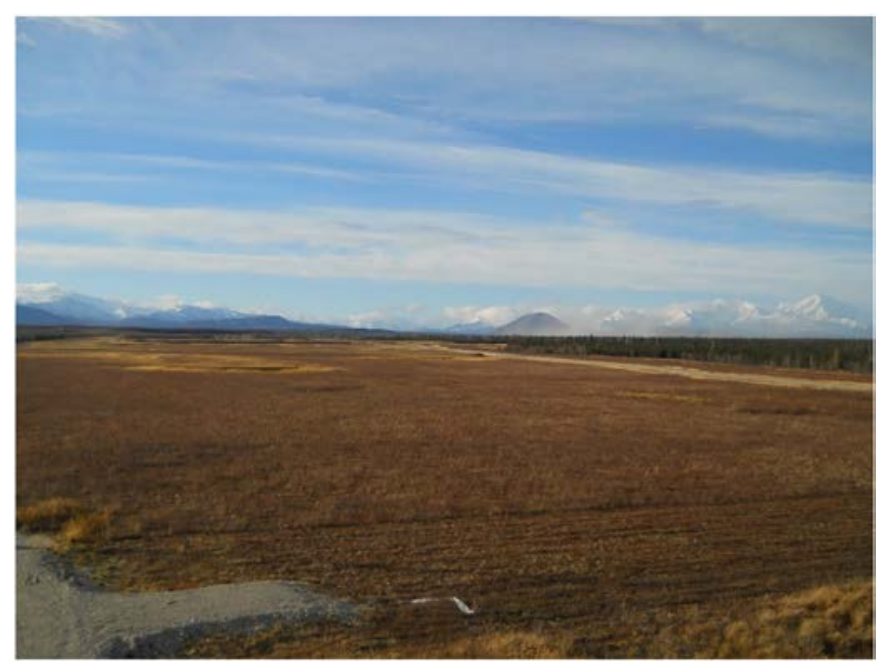

Fig. 4. An example of a Battlerun from a combined arms training facility at Donnelly Training Area East, Alaska. Vehicles with mortars of artillery travel along the gravel roadway and fire at target berms in the distance (photo by T.A. Douglas).

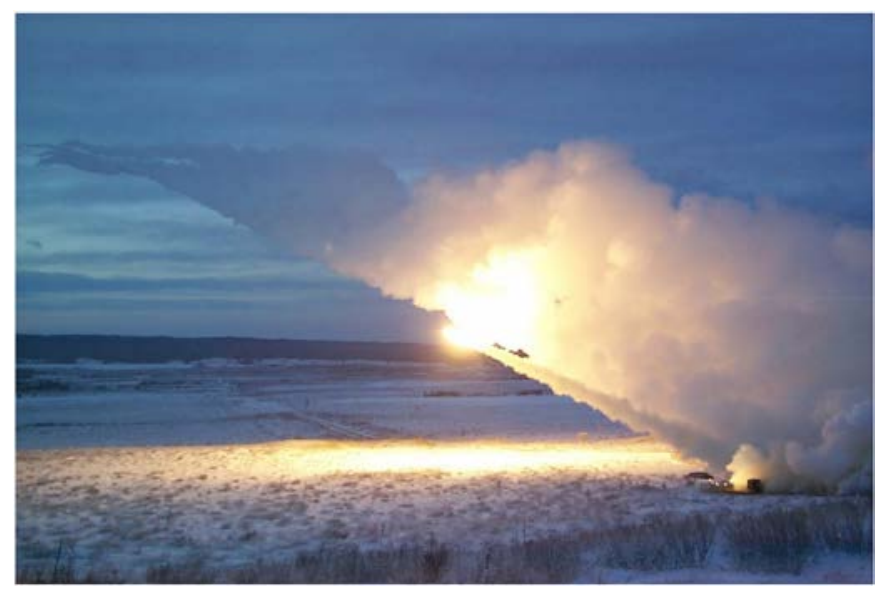

Fig. 5. A winter time rocket test at Donnelly Training Area West, in Alaska. (Photo by T. A. Douglas).

although these ranges were also used for small-arms training. The presence of SAR metals suggests the results are attributable to the small-arms training. Subsurface soils greater than $2 \mathrm{ft}$ (bgs) did not exhibit metal concentrations above background levels and minimal groundwater impacts. Studies of anti-tank and anti-armor ranges at Canadian Forces Base Gagetown found elevated levels of $\mathrm{Cr}, \mathrm{Cd} \mathrm{Cu}$, molybdenum (Mo), $\mathrm{Pb}, \mathrm{Sr}$, and $\mathrm{Zn}$ in surface soils (Thiboutot et al., 2003a). However, the metal constituents of the munitions used for training was not evaluated and compared with observations for the training ranges.

\subsection{Grenade courts}

Training at grenade ranges usually encompasses a relatively small area, less than $8000 \mathrm{~m}^{2}$. Typically, there is a bermed area from behind which a grenade is tossed at a target area. Grenades consist of an explosive (e.g., Composition B) encased in a metal body, which is typically a Fe alloy containing Mn with lesser amounts of $\mathrm{Cu}$ and $\mathrm{Pb}$ (Larson et al., 2009). Soil concentrations of Fe, Zn, Cr, Pb, Ni, Mn, $\mathrm{V}$, and Ca were investigated at two Fort Jackson, S.C. active grenade courts with varied concentrations due to sporadic range maintenance practices (Martin et al., 2013a). Surface soil sampling conducted at two historic grenade courts at Joint Base Cape Cod indicated sporadic elevated results for $\mathrm{Cu}$ and $\mathrm{Pb}$ above established background levels (AMEC, 2001b). The remaining 27 metals analyzed did not indicate elevated concentrations.

\section{Summary}

The majority of metal shooting range studies focus on SARs and concentrations of $\mathrm{Pb}, \mathrm{Sb}$, and $\mathrm{Cu}$, and to a lesser extent $\mathrm{Zn}, \mathrm{As}, \mathrm{Ni}, \mathrm{Cr}$, and W. Future research into SARs should present detailed site information and history, including: site history, soil type, geochemical information, and background values for both soil and aqueous samples. Compiled information that is lacking detail on soils, chemical site parameters, and site history causes difficulty when comparing across sites from different locations around the world.

In general, mortars, artillery, and rockets are used over large areas and a lower number of projectiles are used in training as compared to small-arms ammunition. This lower frequency of use coupled with the principal type of metal in the casing material (i.e., $\mathrm{Al}, \mathrm{Cu}, \mathrm{Fe}$, and $\mathrm{Zn}$ ), their relatively benign toxicology, and limited mobility has resulted in less concern by the military. In contrast, small-arms projectiles are used in large quantities and in small concentrated areas. Thus, there is a potential for a large mass of metal to accumulate over a small area. Because the majority of metal mass is $\mathrm{Pb}$, and it is a known bioaccumulator, a significant amount of research has been conducted on this metal over the past century. Tungsten received recent interest due to it being a possible replacement for $\mathrm{Pb}$ and thus potential for a large mass to build-up. Interest in $\mathrm{W}$ has also been heightened due to toxicological and fate-and-transport concerns. Similarly, interest in Sb has increased due to its toxicological concerns as well as new information suggesting greater mobility in the environment than previously believed despite the small amount of metal in small-arms ammunition. Therefore, most of this review is focused on five metals Sb, $\mathrm{As}, \mathrm{Cu}, \mathrm{Pb}$, and $\mathrm{W}$.

\section{Metals of interest}

\subsection{Antimony}

Antimony is a naturally-occurring metalloid often used as a hardening agent $(0.7-10 \mathrm{wt} \%)$ in the production of the Pb-alloyed core found in small-arms projectiles. In 1990 over 600 tons of Sb was used to manufacture bullets and shot (Martin, 2014). During training exercises, bullets are fired primarily into berm-style backstops or natural hillsides and fragment upon impact. This fragmentation and shattering leads to the exposure of numerous fresh metallic surfaces to weathering processes. The formation of secondary mineral phases during corrosion and/or the direct release of oxidized $\mathrm{Sb}$ into solution from bullet weathering represent a major pathway for introduction of Sb into the environment (Ackermann et al., 2009; Ilgen et al., 2014). Concentrations of Sb at sport shooting ranges often exceed crustal abundances of $0.2 \mathrm{mg} / \mathrm{kg}$ (Onishi and Sandell, 1955) and naturally occurring dissolved Sb concentrations have been estimated at less than $0.1 \mu \mathrm{g} / \mathrm{L}$ for unpolluted waters (Filella et al., 2002). Antimony in soils at sport shooting ranges have been documented to range from $7.40 \pm 6.19$ to $325 \pm 90 \mathrm{mg} / \mathrm{kg}$ (Sanderson et al., 2015), pore waters from 19 to $349 \mu \mathrm{g} / \mathrm{L}$ (Okkenhaug et al., 2016), and Sb has also been found to infiltrate groundwater and local surface water, $11 \pm 2 \mu \mathrm{g} / \mathrm{L}$ and $7.4 \pm 0.1 \mu \mathrm{g} / \mathrm{L}$, respectively (Okkenhaug et al., 2018).

Controlled laboratory studies showed that concentrations of $\mathrm{Sb}$ over $1 \mathrm{mg} / \mathrm{L}$ leached from the full-scale control SAR with leaching up to $0.7 \%$ of the Sb present in 2.5 pore volumes after 12 months of 
rain events (Martin, 2014). Pilot studies with lysimeters demonstrated that $\mathrm{Sb}$ constituted $0.52 \%$ of the total bullet mass, but comprised 91.5 and $17 \%$ of the dissolved leachate metal from control and amended lysimeters, respectively (Martin et al., 2017). Lead constituted $52 \%$ of the total bullet mass but made up only 8.5 and $5 \%$ of the total dissolved leachate metal from the control and amended lysimeters, respectively. Griggs et al. (2011) found that silty sands and poorly graded sands (SM and SP) demonstrated the greatest Sb solubility in post-firing leachate samples. Additionally, $\mathrm{Sb}$ has been shown to accumulate in the shoots and leaves of plants and in soil microbial communities, making Sb bioavailable to higher trophic level organisms (Robinson et al., 2008; Feng et al., 2009; Wilson et al., 2010; Okkenhaug et al., 2011; Shtangeeva et al., 2014; Garau et al., 2017).

Understanding the mobility and toxicity of $\mathrm{Sb}$ is essential for assessing the potential for infiltration into local drinking water and potential short- and long-term impacts to local community health. While shooting ranges are often co-contaminated with a variety of metals, Sb has consistently been found to be more mobile than $\mathrm{Pb}$, despite being present at orders of magnitude less in bullets (Johnson et al., 2005; Klitzke et al., 2012; Martin et al., 2013b; Sanderson et al., 2015; Doherty et al., 2017; Barker et al., 2019a). Unlike $\mathrm{Pb}$, where partitioning between soil and solution is primarily controlled by pH (Clausen et al., 2011a), Sb solubility is highly dependent on speciation and $\mathrm{pH}$. Pentavalent $\mathrm{Sb}[\mathrm{Sb}(\mathrm{V})]$ in solution is more mobile at higher $\mathrm{pH}$ (Hu et al., 2016), while trivalent $\mathrm{Sb}[(\mathrm{Sb}(\mathrm{III})]$ in solution is independent of $\mathrm{pH}$ at environmentally relevant $\mathrm{pH}$ ranges (Johnson et al., 2005). Trivalent Sb has also been shown to have a greater affinity for sorption reactions to Fe substrates over a greater $\mathrm{pH}$ range than $\mathrm{Sb}(\mathrm{V})$. Additionally, the mobility of Sb can be a function of microbial-induced processes (e.g., direct transformations, formation of soluble and insoluble species, induced desorption, competition effects, dissimilatory reduction, presence of solubilized minerals, and dissolution of organic matter). Antimony can still be released from soil/sediment to water when microbial activity is inhibited, suggesting a limited understanding of detailed transport pathways (Rouwane et al., 2016).

Antimony exists in four oxidation states in nature (3-, 0, 3+, and 5+) (Filella et al., 2002; Multani et al., 2016), but primarily occurs in the near-surface environment as $\mathrm{Sb}(\mathrm{III})$ and/or $\mathrm{Sb}(\mathrm{V})$ (Scheinost et al., 2006; Ackermann et al., 2009; Ritchie et al., 2013; Ilgen et al., 2014; Multani et al., 2016). The environmentally relevant aqueous species of $\mathrm{Sb}$ most typically reported are the neutral species, $\mathrm{Sb}(\mathrm{OH})_{3}$, and the oxyanion, $\mathrm{Sb}(\mathrm{OH})_{6}^{-}$(Filella et al., 2002; Filella and May 2003; Wilson et al., 2010; Daus and Hansen, 2016). Key factors influencing speciation include, but are not limited to $\mathrm{pH}$, oxidation-reduction potential ('redox'), dissolved oxygen, biological activity, and co-contamination (Filella et al., 2002; Wilson et al., 2010; Ilgen et al., 2014; Doherty et al., 2017). The oxidation of Sb $\left(\mathrm{Sb}^{0}-\mathrm{Sb}^{\mathrm{III}}-\mathrm{Sb}^{\mathrm{V}}\right)$ has been observed to be relatively fast and in simulated SAR environments (simulated groundwater, cocontaminated with $\mathrm{Pb}$ ), on the order of 5-15 min of reaction time, with $\mathrm{Sb}(\mathrm{V})$ species dominating (Ilgen et al., 2014). Antimony speciation is typically defined by precipitation reactions with calcium (Ca), magnesium ( $\mathrm{Mg}$ ), sodium ( $\mathrm{Na}$ ), and $\mathrm{K}$ for relatively high concentration solution environments as a result of being an oxyanion in solution (Selim, 2012; Ilgen et al., 2014) or sorption reactions with $\mathrm{Fe} / \mathrm{Mn}$ oxyhydroxides, clay minerals, and humic acids (Belzile et al., 2001; Tighe et al., 2005; Leuz and Johnson, 2006; Mitsunobu et al., 2006, 2010; Scheinost et al., 2006; Ackermann et al., 2009; Ilgen and Trainor, 2012), but has also been shown to be controlled by $\mathrm{Sb}$ (III) oxide formation in laboratory-based studies (Ilgen et al., 2014). While the redox environment likely plays a significant role in predicting dominant $\mathrm{Sb}$ species present, $\mathrm{Sb}$ (III) has been found in oxic environments and $\mathrm{Sb}(\mathrm{V})$ has been detected in anoxic environments (Filella et al., 2009). This has led to a relatively limited understanding of the overall environmental factors controlling Sb speciation and thereby, its' fate.

Antimony is considered toxic and the overall toxicity has been found to vary as a function of speciation, in the order of organicallybound $\mathrm{Sb}<\mathrm{Sb}(\mathrm{V})<\mathrm{Sb}$ (III) (Wilson et al., 2010). While Sb has a variety of current-day applications, it has no use in the human body, no known biological function like some other metals, and is considered toxic and a suspected carcinogen (Filella et al., 2002; WHO, 2003). Antimony is often thought to behave similar to As, since they are co-located on the periodic table and, similar to As, trivalent $\mathrm{Sb}$ has been characterized as a suspected carcinogen for almost 20 years and was reevaluated in 2012 (IARC, 2012). While As and $\mathrm{Sb}$ similarities have been touched upon in literature, they do behave differently in terms of oxidation states and general behavior. Interestingly opposite to Sb, As(III) is more soluble and mobile, whereas $\mathrm{As}(\mathrm{V})$ tends to participate in sorption reactions to a greater extent (Wilson et al., 2010). While As has been the subject of numerous studies over the last few decades, Li et al. (2016) concluded that the current understanding of Sb biogeochemistry is roughly equivalent to As understanding, 20 years ago. As such, the contamination of soils, runoff, pore waters, groundwater, and local surface waters with $\mathrm{Sb}$ from shooting range activities provides a potential public health concern and risk for local aquifers and drinking water sources (Herath et al., 2017).

\subsection{Arsenic}

Arsenic is a metalloid that has been found at shotgun shooting ranges as a component of lead-alloyed ammunition $(<0.5 \%$ reported by Scheuhammer and Norris, 1995 and up to $2 \%$ reported by Rooney et al., 1999) and has recently caused issues for overexposure to workers at an indoor gun range (OSHA, 2015). While a wellknown contaminant in other systems, As at shooting ranges is often measured at concentrations close to background levels in soil specific to the area, therefore it is difficult to differentiate the source (Dermatas et al., 2006; Bannon et al., 2009). As exhibits multiple oxidation states in the near-surface environment, but is most often found as $\mathrm{As}(\mathrm{III})$ and/or $\mathrm{As}(\mathrm{V})$, similar to Sb (Wilson et al., 2010). Major environmental factors that affect As mobility are $\mathrm{pH}$, redox, and soil type (Bissen and Frimmel, 2003).

Similar to Sb, As displays complex speciation due to the multiple oxidation states stable in the near-surface environment and toxicity and mobility strongly depend on speciation and environmental setting (Wilson et al., 2010; Ansari et al., 2016). Strong correlations between As concentrations and plants have also been established on military lands and sorption, complexation, and coprecipitation with iron oxyhydroxides, clay minerals, and sulfides are also heavily reported (Wilson et al., 2010; Ansari et al., 2016). Waterlogging conditions, as reported by Lewińska et al. (2019) showed As release was intensified, particular for compost-treated soils, whereas total $\mathrm{Sb}$ concentrations were reduced by water-logging and $\mathrm{Sb}(\mathrm{III})$ tended to increase over time. As such, the complicated nature of $\mathrm{As}$ in co-contaminated soils with $\mathrm{Pb}, \mathrm{Cu}$, and $\mathrm{Sb}$ can present additional challenges similar to $\mathrm{Sb}$ in trying to remediate a site with both anionic and cationic metal(loid)s and reduce the chance for preferential leaching of one type of species versus another. Arsenic has also been shown to form ternary complexes with organic matter with cationic metals acting as a bridging ligand (Martin et al., 2017; Peel et al., 2017).

Arsenic and $\mathrm{Sb}$ are often grouped together as behaving similar in the environment given their proximity on the period table as metalloids and presence as oxyanions in solution (Wilson et al., 
2010). However, As and Sb have fairly opposite speciation behavior in that As fully oxidized as $\mathrm{As}(\mathrm{V})$ is retained by soils and sediments to a greater extent, whereas the fully oxidized $\mathrm{Sb}(\mathrm{V})$ is more mobile. Thus, adding amendments and trying to immobilize As by oxidizing to $\mathrm{As}(\mathrm{V})$ to retain in the system may also oxidize $\mathrm{Sb}$ and cause mobilization. Similarly, a reduction in the system to $\mathrm{Sb}$ (III) decreases Sb mobility, but $\mathrm{As}(\mathrm{III})$ is more mobile in the system (Johnston et al., 2020). Caution should be exercised when adding amendments to any system with more than one contaminant as preferential mobilization as a result of environmental changes can occur. While As remains a heavily studied metal(loid) for contamination in the near surface environment, for SARs studies there exists a lack of knowledge of how As presence can influence mobilization of other metal(loid)s present, particularly $\mathrm{Sb}$ and $\mathrm{Pb}$.

\subsection{Copper}

Copper is typically accounted for in shooting range studies, owing to the use in the casing in mortars, artillery, rockets, targeting equipment, and shell casings. Copper has much higher allowable levels in drinking water $(1300 \mu \mathrm{g} / \mathrm{L})$ in the U.S. than $\mathrm{Pb}$ $(15 \mu \mathrm{g} / \mathrm{L})$ and $\mathrm{Sb}(6 \mu \mathrm{g} / \mathrm{L})$ because of the decreased toxicity and it is an essential micronutrient for plant growth and human and animal health (USEPA, 2009). At higher concentrations in drinking water, however, $\mathrm{Cu}$ can be toxic, and at heavily used shooting ranges concentrations of $\mathrm{Cu}$ can exceed allowable levels (Table 1). Similar to $\mathrm{Pb}$, the solubility of $\mathrm{Cu}$ increases with decreasing $\mathrm{pH}$ and speciation plays a role in overall mobility. Copper has two main oxidation states found in nature $(1+$ and $2+)$, but is predominantly found in the cupric form $(2+)$ in the environment (Ansari et al., 2016; Radar et al., 2019). Toxicity studies show that primary negative effects occur to plants manifesting as decreased plant growth, particularly root growth, and degradation of chlorophyll (Ansari et al., 2016).

At military training lands, the excess of $\mathrm{Cu}$ from the casings and bullet jackets leads to an abundance of $\mathrm{Cu}$ in soils. In literature, $\mathrm{Cu}$ has been shown to have an affinity for organic matter, clay minerals, iron oxides, and sulfides (Ansari et al., 2016; Okkenhaug et al., 2018; Radar et al., 2019). Studies show a strong correlation of $\mathrm{Cu}$ with $\mathrm{pH}$ (lower $\mathrm{pH}$ and presence of DOC attributable to higher $\mathrm{Cu}$ concentrations in surface waters and higher pHs trend to lower concentrations of $\mathrm{Cu}$ ) (Mariussen et al., 2017). There are very few studies that present detailed speciation of $\mathrm{Cu}$ besides oxidation state, there exists very little to no information on local structure of crystalline or amorphous solid-phase $\mathrm{Cu}$ species present on shooting range training lands. Mariussen et al. (2017) did investigate $\mathrm{Cu}$ partitioning in peat samples from a small arms range located in mires and found that a large portion of both $\mathrm{Cu}$ and $\mathrm{Sb}$ were associated with the oxidized components in the peat, which could suggest innersphere complexes with organic matter. This finding suggests $\mathrm{Cu}$ may be similar to $\mathrm{Sb}$ in the formation of innersphere sorption complexes with Fe (Scheinost et al., 2006; Barker et al., 2020) or potentially organic matter and warrants further investigation into the detailed speciation of $\mathrm{Cu}$ on SARs and how that relates to mobility and potential competition for sorption sites with respect to $\mathrm{Sb}$ and $\mathrm{Pb}$.

\subsection{Lead}

Widespread use of $\mathrm{Pb}$ in a variety of everyday activities over the last 50 years and numerous studies on health effects have resulted in a robust understanding of $\mathrm{Pb}$ toxicity. Of the metals in which this review focused $\mathrm{Pb}$ has been studied the most by far. Toxic effects of elevated concentrations of $\mathrm{Pb}$ in humans have resulted in reproductive dysfunction in men and women, brain and nervous system damage, headaches, auditory and vision impairments, high blood pressure, neurological disorders, and memory loss (Apostoli et al., 2006; Mason et al., 2014). Lead has been shown to be transported off-site at sport shooting ranges primarily by dust, which has led to increased health concern over inhalation (Kim et al., 2006). Additionally, high $\mathrm{Pb}$ concentrations in soils has been shown to reduce soil enzyme activity, accumulate in plants, and inhibit photosynthesis and damage DNA in algae (Mozafar et al., 2002; Robinson et al., 2008; Kü; pper, 2017). Altogether, accumulation of $\mathrm{Pb}$ in soils, biota, and plants represents a major health and environmental concern due to the widespread abundance and propensity to bioaccumulate.

Lead is a naturally occurring soft, heavy metal that is the primary chemical constituent often making up 90-99\% of the core of a small arms projectile (Scheuhammer and Norris, 1995; MIDAS, 2010). Significant amounts of $\mathrm{Pb}$ are deposited in soils at sport shooting ranges (Vantelon et al., 2005; Scheuhammer, 2009; Mariussen et al., 2017). This has led to an abundance of studies on $\mathrm{Pb}$ mobility and fate from SARs worldwide over the past 50 years. Concentrations of $\mathrm{Pb}$ in soils found at sport shooting ranges have been found to range from $23 \mathrm{mg} / \mathrm{kg}$ to upwards of $80 \mathrm{~g} / \mathrm{kg}$ (Cao et al., 2003; Knechtenhofer et al., 2003; Mariussen et al., 2017). The solubility of $\mathrm{Pb}$ is highly dependent on $\mathrm{pH}$ and $\mathrm{Pb}$ is more soluble under acidic conditions (Cao et al., 2003; Clausen et al., 2011a; Tandy et al., 2017) and solubilizes at high pHs approximately 10.5 (Barker et al., 2019b). Despite high Pb concentrations often found in soils at shooting ranges, $\mathrm{Pb}$ concentrations in local surface and/or pore waters are generally low, as a result of circumneutral $\mathrm{pHs}$ and the formation of $\mathrm{Pb}$ compounds that are less soluble, particularly phosphates, carbonates, and sulfides and the abundance of surfaces for $\mathrm{Pb}$ to adsorb to (iron/aluminum (oxy) hydroxides, clay minerals, and soil organic matter) (Cao et al., 2003; Knechtenhofer et al., 2003; Scheetz and Rimstidt, 2009; Mariussen et al., 2017; Martin et al., 2017; Sjöstedt et al., 2018; Barker et al., 2019a).

Clausen et al. (2011) exhaustive literature review demonstrated despite widespread use of $\mathrm{Pb}$ in small arms ammunition that $\mathrm{Pb}$ accumulation in surface soils and overall impacts to surface water and groundwater were negligible. In the case of surface water, contamination is primarily the result of sediment mobilization from heavy precipitation events driving runoff into surface water bodies. Consequently, surface water impacts are the result of particulate and not aqueous transport. The situations where aqueous transport occurs are primarily associated with locations were depth to groundwater is shallow and surface water is in direct hydraulic connection with groundwater. Lead mobility depends on a variety of environmental factors, including soil physicochemical properties ( $\mathrm{pH}$, mineral phase assemblage, ionic strength, etc.), rainwater percolation, and co-contaminants present (Cao et al., 2003; Ogawa et al., 2018). Larson et al. (2011) found that differences in mobility were also dependent on the composition of bullets with older antique small-arms ammunition (the 45/70-405 Government) had a lower corrosion and dissolution rate than the $\mathrm{Pb} / \mathrm{Sb}$ alloy of modern ammunition. It is less likely that $\mathrm{Pb}$ will migrate from the older ranges into the surrounding environment either with suspended solids carried by surface water runoff or through leaching into the underlying soil and groundwater. Determining the most abundant chemical species containing $\mathrm{Pb}$ found at shooting ranges and the associated local structure is integral for understanding reactivity, solubility, mobility, bioavailability, and to ascertain the risk posed by high levels of $\mathrm{Pb}$ in the environment (Kelebemang et al., 2017; Sjöstedt et al., 2018). Lead is found in the nearsurface environment at shooting ranges in two oxidation states, $\mathrm{Pb} 2+$ and $\mathrm{Pb} 0$ for unexposed surfaces. When bullets fragment, 

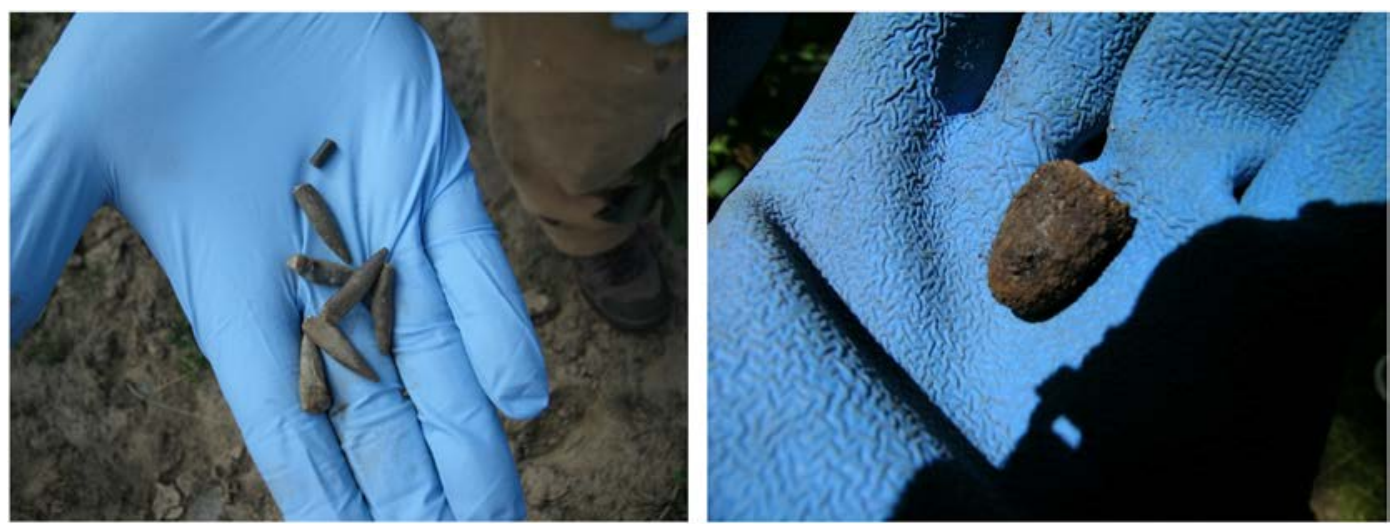

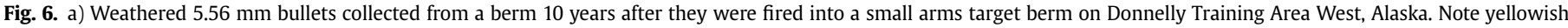

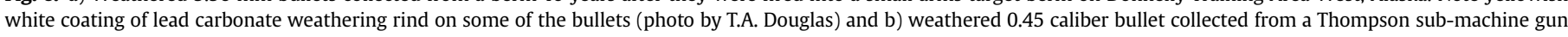
range near the Joint Base Lewis-McChord Evergreen Range recovered over 50 years after it was fired (photo by W.A. Martin).

metallic $\mathrm{Pb}(\mathrm{Pb} 0)$ oxidizes on the surface to form $\mathrm{Pb} 2+$ and can be released directly into soil solution. However, weathering reactions that occur once a bullet is exposed to the environment are responsible for have been found to rapidly form a crust that encases the bullet and comprised of secondary mineral phases, which can also act as a control on Pb solution activity. Fig. 6 shows oxidized crust on the surface of weathered bullets. Speciation data for these bullets is found in Barker et al. (2020). Within typical environmental settings at military shooting ranges, $\mathrm{Pb}$ primarily is found associated with carbonate and oxide (hydrocerussite [Pb3(CO3) $2(\mathrm{OH}) 2]$; cerussite [PbCO3]; polymorphs - litharge and massicot [PbO]), but has also been shown to bind with sulfur and phosphorus depending on mineralogical conditions at a given site (Cao et al., 2003; Vantelon et al., 2005; Scheetz and Rimstidt, 2009; Li et al., 2015). These $\mathrm{Pb}$ oxidation products have limited solubility thus limiting dissolution and subsequent aqueous transport. What tends to be challenging with understanding $\mathrm{Pb}$ mobility and remediating $\mathrm{Pb}$ is how it relates to other metals and metalloids present on site. The presence of both anionic ( $\mathrm{Sb}$ and $\mathrm{As}$ ) and cationic species $(\mathrm{Pb}, \mathrm{Cu}, \mathrm{Ni}, \mathrm{Zn})$ complicates traditional methods (lime, phosphate) and necessitates a more strategic and comprehensive approach. Both $\mathrm{Pb}$ and $\mathrm{Sb}$ are often present as cocontaminates in relatively high concentrations on SAR sites (Table 1) and behave differently geochemically, therefore it is integral to exercise caution when applying amendments or modifying the site because preferential leaching of either $\mathrm{Pb}$ or $\mathrm{Sb}$ can occur when applying traditional remediation techniques primarily targeting only one of the metal species.

\subsection{Tungsten}

Interest in $\mathrm{W}$ biogeochemistry and occurrence has heightened due to human toxicological events, such as the cancer clusters in Fallon, NV, and potentially Sierra Vista, AZ, and Elk Grove, CA, that appear co-located with local natural deposits of W ore (Seiler et al., 2005; Koutsospyros et al., 2006; Mohajerin et al., 2014). Sources of $\mathrm{W}$ releases to the environment include but are not limited to industry (e.g., tungsten carbide tools), agriculture (e.g., fertilizers), civilian activities (e.g., lighting filaments, lead ammunition, fishing accessory replacements), and military activities (e.g., kinetic penetrators, small arms ammunition) (Strigul et al., 2005; Koutsospyros et al., 2006; Kennedy et al., 2012). These concerns resulted in the Centers for Disease Control investigating the link of $\mathrm{W}$ to human health in impacted areas and other public notes on tungsten effects (ATSDR, 2005; Seiler et al., 2005).
Tungsten has been used by the military as replacement for depleted uranium in kinetic penetrators such as anti-tank rounds and a replacement for $\mathrm{Pb}$ in small arms ammunition. Several material properties, such as the high density of $\mathrm{W}$ make it a valuable component of some weapons systems. Because $\mathrm{W}$ has the highest melting point and lowest vapor pressure of all metals it is used in items that require shape and mass retention for optimization of performance. The high tensile strength and excellent corrosion is useful for manufacturing components that must perform in high stress environments. The U.S. Army's Green Ammunition Program developed the $5.56 \mathrm{~mm} \mathrm{~W}$-core projectile as a replacement for $\mathrm{Pb}$ and it was introduced into military inventories in 1999.

While $\mathrm{W}$ was initially thought to be a less toxic alternative to $\mathrm{Pb}$, its sub-lethal effects on certain terrestrial organisms may be greater than $\mathrm{Pb}$ and it appears to be more mobile (Inouye et al., 2006). Tungsten's environmental fate and impact remain active areas of research (Datta et al., 2017; Bostick et al., 2018). Because of the potential for military uses of $\mathrm{W}$ to result in soil, air, and water media containing $\mathrm{W}$ species, research has been conducted in order to: determine the behavior of $\mathrm{W}$ in these media, the effect of $\mathrm{W}$ on environmental receptors, and techniques for accurate determination of the presence and amount of $\mathrm{W}$ in environmental matrices.

Tungsten has multiple oxidation states with +2 and +6 most common with $+4,+5,+6$ forming a variety of complexes in the natural environment, however only the (VI) state is stable in environmentally relevant media and conditions. Tungstate forms through the rapid oxidation of metallic $\mathrm{W}$ to hexavalent $\mathrm{W}(\mathrm{VI})$ (Seiler et al., 2005; Strigul et al., 2005; Koutsospyros et al., 2006). Oxidized tungstates polymerize with other common oxyanions (e.g., molybdate, phosphate, and silicate), thus yielding a variety of polymeric species, each with variable biogeochemical properties and dynamic sorptive behavior (Seiler et al., 2005; Bednar et al., 2007; Johnson, 2009; Griggs et al., 2010a; Kennedy et al., 2012). Bostick et al. (2018) found these polymeric tungstates were weakly adsorbed to soil and predominated over discrete mineral phases. They concluded the high solubilities observed and weak retention onto soil were due to the formation of polyoxometallates such as $\mathrm{W}_{12} \mathrm{SiO}_{40}^{4-}$ in soil solutions. Formation of $\mathrm{W}$ polyoxometallates could increase $\mathrm{W}$ solubility, enhance transport and change its toxicity.

In addition to total or extractable $\mathrm{W}$ analysis, the determination of the poly- and heteropolytungstate species is also important, due to their various biogeochemical characteristics. Work has demonstrated that soluble species may be determined by simple aqueous leaching of soils (Bednar et al., 2008, 2009a, 2009b), and this speciation is important in biological uptake and 
compartmentalization (Kennedy et al., 2012). Additionally, Griggs et al. (2010a) demonstrated differential solubilities of various W compounds can be correlated with solid phases in the soil matrix. The oxyanion state of $\mathrm{W}$ (either as a monomer or polymer) presents analytical determination challenges, particularly during acid extraction from solid matrices (e.g. soils and tissues). The acid extraction conditions, such as those present under common digestion conditions (e.g., USEPA method 3050B), will promote the formation of insoluble polymeric forms, resulting in a low bias. The addition of phosphoric acid, however, can result in the formation of stable and soluble heteropolytungstates that allow for tungsten determination by Inductively Coupled Plasma Atomic Emission Spectroscopy and Mass Spectrometry (ICP-AES and ICP-MS) (Griggs et al., 2009b; Clausen et al., 2010b; Bednar et al., 2010a, 2010b). Furthermore, alkaline extractions have also been shown to be effective, yet can introduce problems with interferences, extraction efficiency, and problematic matrices with the determinative method, or are not suitable to simultaneous determination of other metals (OSHA, 2004; Bednar et al., 2010a).

The complex chemistry described previously is critical to understanding the fate of $\mathrm{W}$ and its behavior in the natural environment. Tungsten can be found co-located with fragmented $\mathrm{Pb}$ bullets on several ranges. Firing of W bullets on SARs that had been, or are concurrently used with traditional $\mathrm{Pb}$ bullets, results in potential bullet on bullet fragmentation of both the $\mathrm{Pb}$ and the $\mathrm{W}$ rounds (Griggs et al., 2010b; Martin, 2014). Scanning electron microscopy and X-ray diffraction analysis of soil particles fired on with tungsten bullets has shown that, contrary to the Pb bullet fragmentation, tungsten produced "smears" and small particles in four of six soil types (O'Connor et al., 2009a,b). Metal fragmentation also leads to changes in metal solubility and leachability (Dermatas et al., 2004; Griggs et al., 2009a). Felt et al. (2009b) determined that bio uptake by the earthworm Eisenia fetida was affected by the presence of $\mathrm{Pb}$, but this was soil type dependent. Soil aging had no effect on uptake of either the $\mathrm{Pb}$ or the $\mathrm{W}$. However, the specific composite formulation of $\mathrm{W}$ shot can influence the mobility of $\mathrm{W}$ in the environment (Felt et al., 2009a, 2011).

Uptake of $\mathrm{W}$ from spiked and aged soils by sunflowers and cabbage resulted in dose dependent toxicological responses, such as reduced growth (Johnson et al., 2009; Kennedy et al., 2012; Lindsay et al., 2017). Tungsten did differentially accumulate into plant tissue. While for sunflowers, concentrations were higher in roots than in stems or leaves (Johnson et al., 2009), W concentrated sufficiently in cabbage, with the highest concentrations in the leaf veins, for significant elevations in concentrations observed in a terrestrial herbivore that consumed the cabbage (Kennedy et al., 2012). Lindsay et al. (2017) demonstrated that trophic transfer of $\mathrm{W}$ from plant to herbivore resulted in: (1) faster and overall greater uptake relative to direct animal exposure to the same contaminated soil and (2) preferential bioaccumulation of monomeric tungsten species in the body of a herbivore, while polymeric $\mathrm{W}$ species preferentially accumulated in the hepatopancreas (an organ similar to liver); in a related study, it was shown the tungsten trophic transfer into a snail resulted in significant concentration in the shell, leading to changes in physical properties, including a weaker shell matrix (Allison et al., 2016).

Other studies have shown that soil type is important in $\mathrm{W}$ bioavailability and mobility, likely from physical distribution in the soil, though chemical sorption and speciation likely affects retention mechanisms (Bednar et al., 2008; Butler et al., 2009). The soil type effect on mobility is likely from physical distribution in the soil (Griggs et al., 2009a), though chemical sorption and speciation likely affects retention mechanisms (Clausen et al., 2007b; Butler et al., 2009; Bednar et al., 2008, 2009b). Additionally, changes to the soil microbiological community as the result of $\mathrm{W}$ have been demonstrated, suggesting this is an important factor in plant response (Ringelberg et al., 2009).

\subsection{Other metals}

Other metals with potential introduction into the environment based on controlled studies with a variety of projectiles include: $\mathrm{Al}$, $\mathrm{Ba}$, beryllium (Be), Cd, Cr, cobalt (Co), Fe, Mg, Mn, mercury ( $\mathrm{Hg}$ ), $\mathrm{Ni}$, and selenium (Se) (Radian, 1999a, 1999b). Many of these metals have been studied across a variety of environmental compartments due to their prevalence and potential contamination risk from nonmilitary activities. However, they have not been studied in great detail with respect to military training activities as dominant source vectors. Aluminum is the primary casing material for antitank rockets and thus is introduced into the environment in fairly large quantities. Iron and $\mathrm{Mn}$ are the primary components for the artillery and mortar casing materials. The remainder of the metals are constituents of various alloying components for the casings, in fuses, or fillers and are present in very small quantities. All of the metals above occur naturally at trace levels in the environment. An exhaustive study assessing the introduction of metals as result of training at Joint Base Cape Cod failed to establish any relationship between any soil metal levels and proximity to targets of any kind (Clausen et al., 2004). In addition, an assessment of groundwater at Joint Base Cape Cod did not indicate the presence of any metal, except for W (AMEC, 2001a). These finding suggest that if metals are being introduced to the environment the load is inconsequential compared to natural background levels with the exception of $\mathrm{Cu}, \mathrm{Pb}, \mathrm{Sb}, \mathrm{W}$, and $\mathrm{Zn}$.

Various pyrotechnic devices have in addition to the above other metals the potential for $\mathrm{Sr}$, which is a primary ingredient in pyrotechnic formulations. Selenium can also be found in igniter compounds and an additive in steel along with $\mathrm{Cr}$ (USACE, 2015), which comprises the bullet core and jackets some bullets, particularly legacy-style small arms ammunition (Barker et al., 2020). Chromium and Se have interesting geochemical behaviors in the environment where $\mathrm{Cr}$ exists as a cation in solution with oxidation states $\mathrm{Cr}(\mathrm{III})$ and $\mathrm{Cr}(\mathrm{VI})$ and $\mathrm{Se}$ is an oxyanion like $\mathrm{As}$ and $\mathrm{Sb}$ and can exist as $\mathrm{Se}(\mathrm{IV})$ and $\mathrm{Se}(\mathrm{VI})$ in the environment (Yang and He, 2016; Martin et al., 2017; Peel et al., 2017). The presence of Cd at shooting ranges tends to be at low concentrations (Dinake et al., 2018a) and is a product of impurities in the Pb alloy (Koons and Grant, 2002). Cadmium is not nearly as studied as $\mathrm{Pb}, \mathrm{Sb}$, or $\mathrm{Cu}$ but has been shown to accumulate in plants (Laghlimi et al., 2015) and be relatively water soluble, which are both concerning attributes coupled with the high toxicity of Cd (Sharma and Sachdeva, 2015). Elevated $\mathrm{Cd}$ concentrations were found in a military shooting range in central Lithuania at concentrations ranging from $17.42 \mathrm{mg} / \mathrm{kg}$ to $39.07 \mathrm{mg} / \mathrm{kg}$ and was found to be higher in the shooting range area than the backstop berm (Česynaitè and Sujetovienè, 2018).

As mentioned previously, metal(loid)s often have an affinity for natural organic matter (NOM), which can act as a sink for both inorganic cations and oxyanions as a result of the heterogeneous nature of NOM. Chromium and Se (in addition to nearly every other metal(loid) mentioned here; $\mathrm{As}, \mathrm{Sb}, \mathrm{Pb}, \mathrm{Fe}, \mathrm{Mn}, \mathrm{Cu}, \mathrm{Ni}, \mathrm{Zn}$, etc.) have been shown in literature to be influenced by NOM in various environmental settings including shooting range systems. Recently, Martin et al. (2017) and Peel et al. (2017) showed that binding reactions between NOM and metal(loid)s may be more complicated than primarily electrostatic interactions and that cation metals (like $\mathrm{Fe}, \mathrm{Cr}$, and $\mathrm{Al}$ ) may facilitate stabilization of oxyanions with NOM by forming ternary complexes and act as a bridge between NOM and the oxyanions. Their findings have significant importance to developing mechanistic transport models of these metals, 
determining the impact metals have on plant function, and understanding the ultimate fate of oxyanions in the environment.

\section{Summary}

Lead geochemical behavior at SARs is widely studied, but there remains a limited understanding of appropriate remediation techniques that will immobilize both cationic and anionic cocontamination successfully, without preferential mobilization. This is a similar finding for each of the metals investigated, as well. Comprehensive approaches to remediating SARs need a specific focus as traditional approaches can have negative effects on preferential leaching of some metals versus others, particularly cationic and anionic species that have varying geochemical behavior in the near surface environment. Tungsten, $\mathrm{Cu}$, and As are often lesser studied and reported in not so much detail as $\mathrm{Pb}$ and $\mathrm{Sb}$, but still play a significant role in making up the environmental system for shooting ranges and thus warrant more of a focus for understanding speciation (specifically for $\mathrm{Cu}$ and $\mathrm{W}$ ) as it relates to: effect of competition for sorption sites, binary and ternary complex mechanistic formation, impact of co-contamination, and formation of innersphere complexes with organic and inorganic ligands.

Antimony is now considered an emerging contaminant and element of interest by the geochemical community and, as such, has seen an abundance of articles published in the last decade. Antimony research areas that require further understanding are microbial-mediated $\mathrm{Sb}$ processes related to $\mathrm{Sb}$ uptake and energy cycling for microorganisms. Similar to Fe and As, Sb likely acts as an acceptable choice for electron transfer for microbial energy production. Additionally, reduced Sb species present in oxic environments and $\mathrm{Sb}(\mathrm{V})$ detected in anoxic environments translates to a relatively limited understanding of the overall environmental factors controlling Sb speciation, such as redox kinetics and influence of microbes. Thus, further work is needed to understand what other environmental factors (i.e., organic matter, colloids, competing ions, sunlight), besides redox environment, play a role in stabilizing oxidized versus reduced $\mathrm{Sb}$ in certain environments.

\section{Conclusions and recommendations for future research}

It is clear from the range of studies discussed in this review that metal speciation is the a priori driver on how, at what rate, and where metals will transition from a bullet, mortar or rocket projectile fragment to adsorbing onto a soil particle or migrating to pore waters or groundwater. In addition, the variety of geochemical conditions present across the training range domain makes it hard to identify any environmental conditions or soil characteristics that could be used to minimize the potential risks of a given metal. Add to this the fact that each metal behaves differently and it is clear that a matrix-based approach is required to design and site, operate, monitor, and remediate ranges across their life cycle. That said, there are few studies documenting the large-scale migration of metals from training ranges to ground water or off-site contamination.

Lead has been studied at sport ranges for over 50 years and, as such, the most is known about the environmental conditions that regulate $\mathrm{Pb}$ in the environment. Tungsten is an emerging metal of concern because of its recent application as a component in military training. Based on a series of studies of $\mathrm{W}$ deposition and fate and ballistics capability issues recent decisions have been made to limit the future use of $\mathrm{W}$ in small-arms. The wealth of studies has shown that $\mathrm{Pb}$ is not very mobile and it has not been detected in groundwater near target ranges despite its' potential centuries of use. Antimony is the metal of most recent concern because it has been understudied, yet many studies have shown that despite it being a small $(\sim 5 \%)$ component in bullets $\mathrm{Sb}$ concentrations in target berm pore waters immediately following training events can be greater than that of $\mathrm{Pb}$. This suggests $\mathrm{Sb}$ oxidizes and goes into solution rapidly. Since $\mathrm{Sb}$ is not used in many other applications there is a limited foundation of studies of Sb deposition, fate, and health concerns compared to $\mathrm{Pb}$ and other metals associated with military events such as $\mathrm{Al}, \mathrm{Cu}, \mathrm{Fe}, \mathrm{Mn}$, and $\mathrm{Zn}$. Copper is an element in need of further research due to both the military and sport shooting industries current reliance as replacement for leaded ammunition.

Promising results from micro-analytical techniques can provide insights into how all of the military-associated metals can be better tracked and managed in the environment. Surface weathering reactions, microbial films, and biogeochemical conditions at a variety of spatial and temporal scales can be better understood by interrogating individual projectile fragments and the soil particles with which they interact. These types of studies should be applied toward all the metals of interest, including $\mathrm{Pb}$, as the speciation and molecular scale interactions between metals and soils have not been well characterized.

From a training range design and management perspective the authors encourage more studies on what types of substrates can be used to promote or prevent the retention of metals in target berm and impact area soils. For example, target berms constructed of large-grained high hydraulic conductivity soil and mineral particles are more likely to be associated with oxidizing conditions. They would thus be less of a long-term sink for metals from training activities but, as a result, would be more likely associated with the release of metals into pore water and perhaps groundwater. There may be locations where this is the preferred situation, for example, where subsurface groundwater sampling and treatment is an option. As a corollary, fine-grained silts and soils that are organic-rich may be more likely to sorb $\mathrm{Pb}$ or Sb (Barker et al., 2019a), which is beneficial in the short-term and in those situations, the soils could be remediated once the site no longer has use. This would decrease the risk of off-site migration but would provide a point source of potentially contaminated soils that would have to be addressed at a future time. Numerous publications exist detailing both effective and ineffective treatment options for metal immobilization and clean-up of military soils. One important note to take away from treatment studies, however, is some traditional treatments (i.e. lime and phosphate) may facilitate metal immobilization in cationic metals like $\mathrm{Pb}, \mathrm{Cu}, \mathrm{Ni}$, and $\mathrm{Zn}$, whereas that same treatment may preferentially mobilize anionic metals like $\mathrm{Sb}$ and As depending on conditions (Kilgour et al., 2008; Klitzke and Lang, 2009; Griggs et al., 2011). Therefore, prior testing of amendments in bench-scale laboratory studies may prove beneficial for assessing potential for metal(loid) mobilization versus immobilization at specific sites before large-scale implementation.

Finally, since metals behave differently in across a variety of environmental conditions and since bullets and projectiles are composed of a variety of metal alloys there is likely no "one design fits all" approach for identifying optimal training range substrate materials. To address this the authors suggest constructing training ranges that are specifically designed for a certain metal source expected for the training types needed. Though this could limit some training activities it would likely reduce the long-term risk of metal migration. 


\section{References}

Ackermann, S., Gieré, R., Newville, M., Majzlan, J., 2009. Antimony sinks in the weathering crust of bullets from Swiss shooting ranges. Sci. Total Environ. 407, 1669-1682.

Agency for Toxic Substances and Disease Registry (ASTDR), 2005. Public Health Statement for Tungsten. Accessed. www.atsdr.cdc.gov/php/phs.asp? $\mathrm{id}=804 \&$ amp; $\mathrm{tid}=157$

Allison, P.G., Seiter, J.M., Diaz, A., Lindsay, J.H., Moser, R.D., Tappero, R.V., Kennedy, A.J., 2016. Gastropod (Otala lactea) shell nanomechanical and structural characterization as a biomonitoring tool for dermal and dietary exposure to a model metal. J Mech Behav Biomed Mater 53, 142-150.

AMEC, 2001a. Final IAGWSP technical team memorandum 01-6 central impact area groundwater report. In: Massachusetts Military Reservation Cape Cod, Massachusetts. MMR-3757. February. AMEC Earth and Environmental, Inc. Westford, MA

AMEC, 2001b. Draft IAGWSP Technical Team Memorandum, Central Impact Area Soil Report. Massachusetts Military Reservation, Cape Cod, MA.

Ansari, A.A., Gill, S.S., Gill, R., Lanza, G.R., Newman, L., 2016. Phytoremediation: Management of Environmental Contaminants, vol. 3. Springer, New York, NY, p. 3.

Apostoli, P., Cornelis, R., Duffus, J., 2006. Elemental Speciation in Human Health Risk Assessment, vol. 234. Environmental Health Criteria, Geneva, pp. 1-256.

Bannon, D.I., Drexler, J.W., Fent, G.M., Casteel, S.W., Hunter, P.J., Brattin, W.J., Major, M.A., 2009. Evaluation of small arms range soils for metal contamination and lead bioavailability. Environ. Sci. Technol. 43 (24), 9071-9076.

Barker, A.J., Douglas, T.A., Ilgen, A.G., Trainor, T.P., 2019a. Lead and antimony from bullet weathering in newly constructed target berms: chemical speciation, mobilization, and remediation strategies. Sci. Total Environ. 658, 558-569.

Barker, A.J., Beal, S., Clausen, J.L., 2019b. Joint Base Cape Cod Small Arms Ranges: Lead and Antimony Batch Reaction Study. US Army Corps of Engineers, Environmental Research and Development Center, Cold Regions Research and Engineering Laboratory, Hanover, NH.

Barker, A.J., Mayhew, L.E., Douglas, T.A., Ilgen, A.G., Trainor, T.P., 2020. Lead and antimony speciation associated with the weathering of bullets in a historic shooting range in Alaska. In: Chemical Geology. Press.

Basunia, S., Landsberger, S., 2001. Contents and leachability of heavy metals ( $\mathrm{Pb}, \mathrm{Cu}$, $\mathrm{Sb}, \mathrm{Zn}, \mathrm{As}$ ) in soil at the Pantex firing range, Amarillo, Texas. Air Waste Manage. Assoc. 51, 1428-1435.

Bednar, A.J., Mirecki, J.E., Inouye, L.S., Winfield, L.E., Larson, S.L., Ringelberg, D.B., 2007. The determination of tungsten, molybdenum, and phosphorus oxyanions by high performance liquid chromatography inductively coupled plasma mass spectrometry. Talanta 72 (5), 1828-1832.

Bednar, A.J., Jones, W.T., Boyd, R.E., Ringelberg, D.B., Larson, S.L., 2008. Geochemical parameters influencing Tungsten mobility in soils. J. Environ. Qual. 37, 229-233.

Bednar, A.J., Kirgan, R.A., Johnson, D.R., Russell, A.L., Hayes, C.A., McGrath, C.J., 2009a. Polytungstate analysis by SEC-ICP-MS and direct infusion ESI-MS. Land Contam. Reclamat 17, 129.

Bednar, A.J., Boyd, R.E., Jones, W.T., McGrath, C.J., Johnson, D.R., Chappell, M.A., Ringelberg, D.B., 2009b. Investigations of tungsten mobility in soil using column tests. Chemosphere 75, 1049-1056.

Bednar, A.J., Griggs, C.S., Hill, F.C., 2010. Addendum to "A modified acid digestion procedure for extraction of tungsten from soil. Talanta 82, 1627-1628.

Bednar, A.J., Jones, W.T., Chappell, M.A., Johnson, D.R., Ringelberg, D.B., 2010. A modified acid digestion procedure for extraction of tungsten from soil. Talanta 80, 1257-1263.

Belzile, N., Chen, Y.W., Wang, Z., 2001. Oxidation of antimony (III) by amorphous iron and manganese oxyhydroxides. Chem. Geol. 174, 379-387.

Bissen, M., Frimmel, F.H., 2003. Arsenic - a review. Part I: occurrence, toxicity, speciation, mobility. Soil Air Water 31 (1), 9-18.

Bostick, B., Sun, J., Landis, J., Clausen, J., 2018. Tungsten speciation and solubility in munitions-impacted soils. Environ. Sci. Technol. 52 (3), 1045-1053.

Brannon, J.M., Jenkins, T.F., Parker, L.V., Deliman, P., Gerald, J.A., 2000. Procedures for determining integrity of UXO and explosives soil contamination at firing ranges. Technical Report ERDC TR-00-4. (ERDC/CRREL MP-01-5604) 39.

Braun, U., Pusterla, N., Ossent, P., 1997. Lead poisoning of calves pastured in the target area of a military shooting range. Schweiz. Arch. Tierheilkd. 139, 403-407.

Bruell, R., Nikolaidis, N.P., Long, R.P., 1999. Evaluation of remedial alternatives of lead from shooting range soil. Environ. Eng. Sci. 16 (5), 403-414.

Busby, R.R., Douglas, T.A., LeMonte, J.J., Ringelberg, D.B., Indest, K.J., 2019. Metal accumulation capacity in indigenous Alaska vegetation growing on military training lands. Int. J. Phytoremediation 22 (3), 259-266.

Butler, A.D., Medina, V.F., Larson, S., Nestler, C., 2009. Uptake of lead and tungsten in Cyperus esculentus in a small-arms range simulation. Land Contam. Reclamat. $17,153$.

Cao, X., Lena, Q.M., Chen, M., Hardison Jr., D.W., Harris, W.G., 2003. Weathering of lead bullets and their environmental effects at outdoor shooting ranges. J. Environ. Qual. 32, 526-534.

Čsynaite, J., Sujetoviene, G., 2018. Change in soil properties and heavy metals concentration in soil of military shooting range in Central Lithuania. Environ. Res. Eng. Manag. 74 (4), 53-59.

Clausen, J., Korte, N., 2009a. The distribution of metals in soils and pore water at three U.S. military training facilities. Soil and Sediment Contamination Journal: Int. J. 18 (5), 546-563.

Clausen, J.L., Korte, N., 2009b. Environmental fate of tungsten from military use. Sci. Total Environ. 407 (8), 2887-2893.

Clausen, J.L., Robb, J., Curry, D., Gregson, B., Korte, N., 2004. A case study of contaminants on military ranges: camp Edwards, Massachusetts, USA. Environ. Pollut. 129, 13-21.

Clausen, J.L., Korte, N., Bostick, B., Rice, B., Walsh, M., Nelson, A., 2007a. Environmental Assessment of Lead at Camp Edwards, Massachusetts Small Arms Ranges. ERDC-CRREL TR-07-11. US Army Corps of Engineers, Environmental Research and Development Center, Cold Regions Research and Engineering Laboratory, Hanover, NH.

Clausen, J., Taylor, S., Larson, S., Bednar, A., Ketterer, M., Griggs, C., Lambert, D. Hewitt, A., Ramsey, C., Bigl, S., Bailey, R., Perron, N., 2007b. Fate and Transport of Tungsten at Camp Edwards Small Arms Ranges. ERDC-CRREL TR-07-05. US Army Corps of Engineers, Environmental Research and Development Center, Cold Regions Research and Engineering Laboratory, Hanover, NH.

Clausen, J.L., Bednar, A., Lambert, D., Bailey, R., Kuhlbrush, M., Taylor, S., Bigl, S., 2010a. Phase II Tungsten Fate-And-Transport Study for Camp Edwards. ERDCCRREL TR-10-3. US Army Corps of Engineers, Environmental Research and Development Center, Cold Regions Research and Engineering Laboratory, Hanover, $\mathrm{NH}$.

Clausen, J.L., Ketterer, M.E., Bednar, A.J., Koenig, M.R., 2010b. Challenges and successes in using inductively coupled plasma mass spectrometry for measurements of tungsten in environmental water and soil samples. Int. J. Environ. Anal. Chem. 90, 773-783.

Clausen, J.L., Bostick, B., Korte, N., 2011a. Migration of lead in surface water, pore water, and groundwater with a focus on firing ranges. Crit. Rev. Environ. Sci. Technol. 41 (15), 1397-1448.

Clausen, J.L., Bostick, B., Bednar, A., Sun, S., Landis, J.D., 2011b. Tungsten Speciation in Firing Range Soils. US Army Corps of Engineers, Environmental Research and Development Center, Cold Regions Research and Engineering Laboratory, Hanover, $\mathrm{NH}$.

Clausen, J.L., Richardson, J., Korte, N., Gooch, G., Hall, T., Perron, N., Butterfield, E. Walsh, M.E., Taylor, S., 2012. Metal residue deposition from military pyrotechnic devices and field sampling guidance. In: ADA565449. Prepared for U.S. Army Environmental Command. US Army Corps of Engineers, Environmenta Research and Development Center, Cold Regions Research and Engineering Laboratory, Hanover, NH.

Craig, J.R., Edwards, D., Rimstidt, J.D., Scanlon, P.F., Collins, T.K., Schabenberger, O. Birch, J.B., 2002. Lead distribution on a public shotgun range. Environ. Geol. 41, $873-882$.

Datta, S., Vero, S.E., Hettiarachichi, G.M., Johannesson, K., 2017. Tungsten contamination of soils and sediments: current state of the science. Landerber. Pol. https://doi.org/10.1007/s40726-016-0046-0.

Daus, B., Hansen, H.R., 2016. Analysis of antimony species - lessons learnt from more than two decades of environmental research. Environ. Chem. 13, 913-918.

Dermatas, D., Braida, W., Christodoulatos, C., Strigul, N., Panikov, N., Los, N. Larson, S.L., 2004. Solubility, sorption and soil respiration effects of tungsten and tungsten alloys. Journal of Environmental Forensics 5 (1), 5-13.

Dermatas, D., Cao, X., Tsaneva, V., Shen, G., Grubb, D.G., 2006. Fate and behavior of metal contaminants in an organic matter-rich shooting range soil: implications for remediation. Water Air Soil Pollut. Focus 6 (1-2), 143-155.

Dinake, P., Maphane, O., Sebogisi, K., Kamwi, O., 2018a. Pollution status of shooting range soils from $\mathrm{Cd}, \mathrm{Cu}, \mathrm{Mn}, \mathrm{Ni}$ and $\mathrm{Zn}$ found in ammunition. Cogent Environmental Science 4,1 .

Doherty, S.J., Tighe, M.K., Wilson, S.C., 2017. Evaluation of amendments to reduce arsenic and antimony leaching from co-contaminated soils. Chemosphere 174, 208-217.

Duggan, J., Dhawan, A., 2007. Speciation and vertical distribution of lead and lead shot in soil at a recreational firing range. Soil Sediment Contam. 16, 351.

Dvorak, P., Roy, K., Andreji, J., Liskova, Z.D., Mraz, J., 2020. Vulnerability Assessment of Wild Fish Population to Heavy Metals in Military Training Area: Synthesis of a Framework with Example from Czech Republic. https://doi.org/10.1016/ j.ecolind.2019.105920.

Evangelou, M.W., Hockmann, K., Pokharel, R., Jakob, A., Schulin, R., 2012. Accumulation of $\mathrm{Sb}, \mathrm{Pb}, \mathrm{Cu}, \mathrm{Zn}$ and $\mathrm{Cd}$ by various plants species on two different relocated military shooting range soils. J. Environ. Manag. 108, 102-107.

Felt, D., Griggs, C., Larson, S., Nestler, C., Thompson, M., 2009a. Dissolution of tungsten-tin compared to tungsten-nylon rounds. Land Contam. Reclamat. 17, 59-66.

Felt, D., Larson, S., Griggs, C., Nestler, C., Thompson, M., 2009b. The potential for bioaccumulation of tungsten in earthworms - the effect of legacy lead on biouptake. Land Contam. Reclamat. 17, 161-167.

Felt, D., Larson, S., Griggs, C., Nestler, C., Thompson, M., 2011. Relationship of surface charge to metal leaching from tungsten composite shot exposed to three different soil types. Chemosphere 83 (7), 955-962.

Feng, R.W., Wei, C.Y., Tu, S.X., Wu, F.C., Yang, L.S., 2009. Antimony accumulation and antioxidative responses in four fern plants. Plant Soil 317, 93-101.

Filella, M., May, P.M., 2003. Computer simulation of the low-molecular-weight inorganic species distribution of antimony(III) and antimony(V) in natural waters. Geochem. Cosmochim. Acta 67 (21), 4013-4031.

Filella, M., Belzile, N., Chen, Y.W., 2002. Antimony in the environment: a review focused on natural waters I. Occurrence. Earth Sci. Rev. 57, 125-176.

Filella, M., Williams, P.A., Belzile, N., 2009. Antimony in the environment: knowns 
and unknowns. Environ. Chem. 6 (2), 95.

Garau, G., Silvetti, M., Vasileiadis, S., Donner, E., Diquattro, S., Deiana, S., Lombi, E., Castaldi, P., 2017. Use of municipal solid wastes for chemical and microbiological recovery of soils contaminated with metals. Soil Biol. Biochem. 111, 25-35.

Griggs, C., Larson, S., Johnson, J., Felt, D., Nestler, C., 2009a. Partitioning between aqueous and soil system components for soluble tungsten and lead species. Land Contam. Reclamat. 17, 83-91.

Griggs, C., Larson, S., Nestler, C., Thompson, M., 2009b. Coupling of oxygen and pH requirements for effective microwave-assisted digestion of soils for tungsten analysis. Land Contam. Reclamat. 17, 121.

Griggs, C., Larson, S., Liu, G., Felt, D., Martin, W.A., Thompson, M., Nestler, C., 2010a. Solid-phase tungsten speciation by differential digestion. Environ. Forensics 11, 275.

Griggs, C.S., Larson, S.L., O'Connor, G., 2010b. Fragmentation and distribution of lead following firing into various types of range soils. In: GeoFlorida 2010: Advances in Analysis, Modeling \& Design, pp. 2741-2748.

Griggs, C.S., Martin, W.A., Larson, S.L., O'Connor, G., Fabian, G., Zynda, G., Mackie, D., 2011. The effect of phosphate application on the mobility of antimony in firing range soils. Sci. Total Environ. 409, 2397-2403.

Guemiza, K., Mercier, G., Blais, J.-F., 2014. Pilot-scale counter-current acid leaching process for $\mathrm{Cu}, \mathrm{Pb}, \mathrm{Sb}$, and $\mathrm{Zn}$ from small-arms shooting range soil. J. Soils Sediments 14, 1359-1369.

Hardison Jr., D.W., Ma, L.Q., Luongo, T., Harris, W.G., 2004. Lead contamination in shooting range soils from abrasion of lead bullets and subsequent weathering. Sci. Total Environ. 328, 175-183.

Herath, I., Vithanage, M., Bundschuh, 2017. Antimony as a global dilemma: geochemistry, mobility, fate and transport. Environ. Pollut. 223, 545-559.

Hu, X., Guo, X., He, M., Li, S., 2016. pH-dependent release characteristics of antimony and arsenic from typical antimony-bearing ores. J. Environ. Sci. 44, 171-179.

Ilgen, A., Trainor, T., 2012. Sb(III) and Sb(V) sorption onto Al-rich phases: hydrous Al oxide and the clay minerals kaolinite KGa-1b and oxidized and reduced nontronite NAu-1. Environ. Sci. Technol. 46, 843-851.

Ilgen, A.G., Majs, F., Barker, A.J., Douglas, T.A., Trainor, T.P., 2014. Oxidation and mobilization of metallic antimony in aqueous systems with simulated groundwater. Geochem. Cosmochim. Acta 132, 16-30.

Inouye, L.S., Jones, R.P., Bednar, A.J., 2006. Tungsten effects on survival, growth, and reproduction in the earthworm, eisenia fetida. Environ. Toxicol. Chem. 25, 763-768.

International Agency for Research on Cancer, 2012. IARC Monograph 100C. World Health Organization.

Interstate Technology and Regulatory Council, 2003. Characterization and remediation of soils at closed small arms firing ranges. Small Arms Firing Range Team.

Islam, M.N., Nguyen, X.P., Jung, H.Y., Park, J.H., 2015. Chemical speciation and quantitative evaluation of heavy metal pollution hazards in two Army shooting range backstop soils. Bull. Environ. Contam. Toxicol. 96, 179-185.

Jardine, P.M., Parker, J.C., Stewart, M.A., Barnett, M.O., Fendorf, S.E., 2007. Decreasing toxic metal bioavailability with novel soil amendment strategies. SERDP ER1350 Final Report, p. 22

Jenkins, T.F., Pennington, J.C., Ranney, T.A., Berry Jr., T.E., Miyares, P.H., Walsh, M.E., Hewitt, A.D., Perron, N.M., Parker, L.V., Hayes, C.A., Wahlgren, E.G., 2001. Characterization of explosives contamination at military firing ranges. Technical Report ERDC TR-01-5. 36 pgs.

Jenkins, T.F., Hewitt, A.D., Walsh, M.E., Ranney, T.A., Ramsey, C.A., Grant, C.L., Bjella, K.L., 2006. Representative sampling for energetic compounds at military training ranges. Environ. Forensics 6 (1), 45-55.

Johnson, C., Moench, H., Wersin, P., Kugler, P., Wenger, C., 2005. Solubility of antimony and other elements in samples taken from shooting ranges. J. Environ. Qual. 34, 248.

Johnson, D.R., Inouye, L.S., Bednar, A.J., Clarke, J.U., Winfield, L.E., Boyd, R.E., Ang, C.Y., Goss, J., 2009. Tungsten bioavailability and toxicity in sunflowers. Land Contam. Reclamat. 17, 141-152.

Johnston, S.G., Bennett, W.W., Doriean, N., Hockmann, K., Karimian, N., Burton, E.D., 2020. Antimony and arsenic speciation, redox-cycling and contrasting mobility in a mining-impacted river system. Sci. Total Environ. 710, 136354.

Kelebemang, R., Dinake, P., Sehube, N., Daniel, B., Totolo, O., Laetsang, M., 2017. Speciation and mobility of lead in shooting range soils. Chem. Speciat. Bioavailab. 29 (1), 143-152.

Kennedy, A.J., Johnson, D.R., Seiter, J.M., Lindsay, J.H., Boyd, R.E., Bednar, A.J., Allison, P.G., 2012. Tungsten toxicity, bioaccumulation, and compartmentalization into organisms representing two trophic levels. Environ. Sci. Technol. 46, 9646.

Kilgour, D.W., Moseley, R.B., Barnett, M.O., Savage, K.S., Jardine, P.M., 2008. Potential negative consequences of adding phosphorus-based fertilizers to immobilize lead in soil. J. Environ. Qual. 37 (5), 1733-1740.

Kim, K.H., Kang, C.H., Lee, J.H., Choi, K.C., Youn, Y.H., Hong, S.M., 2006. Investigation of airborne lead concentrations in relation to Asian Dust events and air mass transport pathways. J. Aerosol Sci. 37 (12), 1809-1825.

Klitzke, S., Lang, F., 2009. Mobilization of soluble and dispersible lead, arsenic, and antimony in a polluted, organic-rich soil - effects of $\mathrm{pH}$ increase and counterion valency. J. Environ. Qual. 38 (3), 933-939.

Klitzke, S., Lang, F., Kirby, J., Lombi, E., Hamon, R., 2012. Lead, antimony and arsenic in dissolved and colloidal fractions from an amended shooting-range soil as characterized by multi-stage tangential ultrafiltration and centrifugation. Environ. Chem. 9, 462-473.

Knechtenhofer, L.A., Xifra, I.O., Scheinost, A.C., Flühler, H., Kretzschmar, R., 2003.
Fate of heavy metals in a strongly acidic shooting-range soil: small-scale metal distribution and its relation to preferential water flow. J. Plant Nutr. Soil Sci. 166 (1), 84-92.

Koons, R.D., Grant, D.M., 2002. Compositional variation in bullet lead manufacture. J. Forensic Sci. 47 (5), 950-958.

Koutsospyros, A., Braida, W., Christodoulatos, C., Dermatas, D., Strigul, N., 2006. A review of tungsten: from environmental obscurity to scrutiny. J. Hazard Mater. 136, 1-19.

Labare, M.P., Butkus, M.A., Riegner, D., Schommer, N., Atkinson, J., 2004. Evaluation of lead movement from the abiotic to biotic at a small-arms firing range. Environ. Geol. 46 (6), 750-754.

Laghlimi, M., Baghdad, B., El Hadi, H., Bouabdli, A., 2015. Phytoremediation mechanisms of heavy metal contaminated soils: a review. Open J. Ecol. 5, 375-388.

Laidlaw, M.A.S., Filippelli, G., Mielke, H., Gulson, B., Ball, A.S., 2017. Lead exposure at firing ranges-a review. Environ. Health 16, 34.

Laporte-Saumure, M. Martel, R., 2011. Mercier G. Characterization and metal availability of copper, lead, antimony and zinc contamination at four Canadian small arms firingranges. Environ. Technol. 32 (7), 767-781.

Larson, S.L., Teeter, C.L., Medina, V.F., Martin, W.A., 2007a. Treatment and Management of Closed or Inactive Small Arms Firing Ranges. U.S. Army Engineer Research and Development Center, Environmental laboratory, Vicksburg, MS.

Larson, S.L., Malone, P.G., Weiss, C.A., Martin, W.A., Trest, C., Fabian, G. Warminsky, M.F., Mackie, D., Tasca, J.J., Wildey, J., Wright, J., 2007b. Amended Ballistic Sand Studies to Provide Low Maintenance Lead Containment at Active Small Arms Firing Range Systems. ERDC-EL TR-07-14. U.S. Army Engineer Research and Development Center, Environmental laboratory, Vicksburg, MS.

Larson, S.L., Davis, J.L., Martin, W.A., Felt, D.R., Nestler, C.C., Fabian, G.L., O'Connor, G., 2009. Hand Grenade Residuals. ERDC-EL TR-09-2. U.S. Army Engineer Research and Development Center, Environmental laboratory, Vicksburg, MS.

Larson, S.L., Martin, W.A., Griggs, C.S., Thompson, M., Nestler, C.C., 2011. Comparison of lead dissolution from antique and modern ammunition. Environ. Forensics 12, 149-155.

Larson, S.L., Martin, W.A., Dortch, M.S., Thomas, C.C., Griggs, C.S., Nestler, C.C., 2016. Flexible Reactive Berm (FRBerm) for Removal of Heavy Metals from Runoff Water. ERDC-EL TR-16-7. U.S. Army Engineer Research and Development Center, Environmental laboratory, Vicksburg, MS.

Leuz, A.K., Johnson, C.A., 2006. Sorption of Sb(III) and Sb(V) to goethite: influence on Sb(III) oxidation and mobilization. Environ. Sci. Technol. 40 (23), 7277-7282.

Lewińska, K., Karczewska, A., 2019. A release of toxic elements from military shooting range soils as affected by $\mathrm{pH}$ and treatment with compost. Geoderma 346, 1-10.

Lewińska, K., Karczewska, A., Siepak, M., Szopka, K., Gałka, B., Iqbal, M., 2019. Effects of waterlogging on the solubility of antimony and arsenic in variously treated shooting range soils. Appl. Geochem. 105, 7-16.

Li, Y., Zhu, Y., Zhao, S., Liu, X., 2015. The weathering and transformation process of lead in China's shooting ranges. Environ. Sci. J. Integr. Environ. Res.: Processes \& Impacts 17, 1620-1633.

Li, J., Wang, Q., Oremland, R.S., Kulp, T.R., Rensing, C., Wang, G., 2016. Microbial antimony biogeochemistry: enzymes, regulation, and related metabolic pathways. Appl. Environ. Microbiol. 82 (18), 5482-5495.

Lindsay, J.H., Kennedy, A.J., Seiter-Moser, J.M., Bednar, A.J., Boyd, R.E., Johnson, D.R., Allison, P., Tappero, R.V., 2017. Uptake kinetics and trophic transfer of tungsten from cabbage to a herbivorous animal model. Environ. Sci. Technol. 51, 13755-13762.

Mariussen, E., Johnsen, I.V., Strømseng, A.E., 2017. Distribution and mobility of lead $(\mathrm{Pb})$, copper $(\mathrm{Cu})$, zinc $(\mathrm{Zn})$, and antimony $(\mathrm{Sb})$ from ammunition residues on shooting ranges for small arms located on mires. Environ. Sci. Pollut. Res. 24 (11), 10182-10196.

Martin, W.A., 2014. Antimony Environmental Interactions and Sequestration Associated with Amendments and Small Arms Firing Ranges. Purdue University Dissertation.

Martin, W.A., Felt, D.R., Nestler, C.C., Fabian, G., O’Connor, G., Larson, S.L., 2013a Hydrated lime for metal immobilization and explosives transformation: field demonstration. J. Hazard. Toxic Radioact. Waste, ASCE. 17, 237-244.

Martin, W.A., Lee, L.S., Schwab, P., 2013b. Antimony migration trends from a small arms firing range compared to lead, copper, and zinc. Sci. Total Environ. 463-464, 222-228

Martin, W.A., Nestler, C.C., Wynter, M., Larson, S.L., 2014. Bullet on bullet fragmentation profile in soils. J. Environ. Manag. 146, 369-372.

Martin, W.A., Nestler, C.C., Lee, L.S., Larson, S.L., 2017. Range design considerations based on behavior of antimony and lead under dynamic loading conditions. J. Environ. Eng. 143, 7.

Martin, D.P., Seiter, J.M., Lafferty, B.J., Bednar, A.J., 2017. Exploring the ability of cations to facilitate binding between inorganic oxyanions and humic acid Chemosphere 166, 192-196.

Mason, L.H., Harp, J.P., Han, D.Y., 2014. Pb Neurotoxicity: neuropsychological effects of lead toxicity. BioMed Res. Int. 8.

Mellor, A., McCartney, C., 1994. The effects of lead shot deposition on soils and crops at a clay pigeon shooting site in northern England. Soil Use Manag. 10, 124-129.

Migliorini, M., Pigino, G., Bianchi, N., Bernini, F. Leonzio, C., 2004. The effects of heavy metal contamination on the soil arthropod community of a shooting range. Environ. Pollut. 129, 331-340.

Mitsunobu, S., Harada, T., Takahashi, Y., 2006. Comparison of antimony behavio with that of arsenic under various soil redox conditions. Environ. Sci. Technol. 40, 7270-7276. 
Mitsunobu, S., Takahashi, Y., Terada, Y., Sakata, M., 2010. Antimony (V) Incorporation into synthetic ferrihydrite, goethite, and natural iron oxyhydroxides. Environ. Sci. Technol. 44 (10), 3712-3718.

Mohajerin, T.J., Neal, A.W., Telfeyan, K., Sasihharan, S.M., Ford, S., Yang, N., Chevis, D.A., Grimm, D.A., Datta, S., White, C.D., Johannesson, K.H., 2014. Geochemistry of tungsten and arsenic in aquifer systems: a comparative study of groundwaters from West Bengal, India, and Nevada, USA. Water, Air, Soil Pollut. 225, 1792.

Mozafar, A., Ruh, R., Klingel, P., Gamper, H., Egli, S., Frossard, E., 2002. Effect of heavy metal contamination shooting range soils on mycorrhizal colonization of roots and metal uptake by leek. Environ. Monit. Assess. 79, 177-191.

Multani, R.S., Feldmann, T., Demopoulos, G.P., 2016. Antimony in the metallurgical industry: a review of its chemistry and environmental stabilization options. Hydrometallurgy 164, 141-153.

Murray, K., Bazzi, A., Carter, C., Ehlert, A., Harris, A., Kopec, M., Richardson, J., Sokol, H., 1997. Distribution and mobility of lead in soils at an outdoor shooting range. J. Soil Contam. 6, 79-93.

Occupational Safety and Health Administration, 2004. Tungsten and Cobalt in Workplace Atmospheres (ICP-AES Analysis).

Ogawa, S., Katoh, M., Sato, T., 2015. Simultaneous lead and antimony immobilization in shooting range soil by a combined approach of hydroxyapatite and ferrihydrite. Environ. Technol. 36 (20), 2647-2656.

Ogawa, S., Katoh, M., Numako, C., Kitahar, K., Miyazaki, S, Sato, T, 2016. Immobilization of Antimony(III) in oxic soil using combined application of hydroxyapatite and ferrihydrite. Water Air Soil Pollut. 227, 124.

Ogawa, S., Sato, T., Katoh, M., 2018. Formation of a lead-insoluble phase, pyromorphite, by hydroxyapatite during lead migration through the waterunsaturated soils of different lead mobilities. Environ. Sci. Pollut. Control Ser. 25 (8), 7662-7671.

Ogden, 2000. Final IAGS Technical Team Memorandum 99-1 KD \& U Ranges for the Camp Edwards Impact Area Groundwater Quality Study, Massachusetts Military Reservation Cape Cod, Massachusetts. MMR-1903. July. Ogden Environmental and Energy Services. Westford, MA.

Okkenhaug, G., Zhu, Y.G., Luo, L., Lei, M., Li, X., Mulder, J., 2011. Distribution, speciation and availability of antimony ( $\mathrm{Sb}$ ) in soils and terrestrial plants from an active Sb mining area. Environ. Pollut. 159, 2427-2434.

Okkenhaug, G., Amstätter, K., Bue, H.L., Cornelissen, G., Breedveld, G.D., Henriksen, T., Mulder, J., 2013. Antimony (Sb) contaminated shooting range soil: Sb mobility and immobilization by soil amendments. Environ. Sci. Technol. 47, 6431-6439.

Okkenhaug G. Gebhardt, K.A.G., Amstaetter, K., Bue, H.L., Herzel, H., Mariussen, E. Almås, Å.R., Cornelissen, G., Breedveld, G.D., Rasmussen, G., Mulder, J., 2016. Antimony $(\mathrm{Sb})$ and lead $(\mathrm{Pb})$ in contaminated shooting range soils: $\mathrm{Sb}$ and $\mathrm{Pb}$ mobility and immobilization by iron based sorbents, a field study. J. Hazard Mater. 307, 336-343.

Okkenhaug, G., Smebye, A.B., Pabst, T., Amundsen, C.E., Sævarsson, H., Breedveld, G.D., 2018. Shooting range contamination: mobility and transport of lead $(\mathrm{Pb})$, copper $(\mathrm{Cu})$ and antimony $(\mathrm{Sb})$ in contaminated peatland. J. Soils Sediments 18, 3310-3323.

Onishi, H., Sandell, E.B., 1955. Notes on the geochemistry of antimony. Geochem. Cosmochim Acta 8, 213-221.

O’Connor, G., Martin, W.A., Larson, S.L., Weiss, C., 2009a. Distribution of tungsten on soil particles following firing of tungsten ammunition into various soil types. Land Contam. Reclamat. 17 (1), 67-73.

O'Connor, G., Martin, W.A., Larson, S.L., Weiss, C., Malone, P., 2009b. Distribution of tungsten on soil particles following firing of tungsten ammunition into various soil types. Land Contam. Reclamat. 17, 67-73.

Pain, D.J., Dicki, I., Green, R.E., Kanstrup, N., Cromie, R., 2019. Wildlife, human and environmental costs of using lead ammunition: an economic review and analysis. Ambio 48, 969-988.

Peel, H.R., Martin, D.P., Bednar, A.J., 2017. Extraction and characterization of ternary complexes between natural organic matter, cations, and oxyanions, from a natural soil. Chemosphere 176, 125-130.

Pennington, J.C., Silverblatt, B., Poe, K., Hayes, C.A., Yost, S., 2008. Explosive residues from low-order detonations of heavy artillery and mortar rounds. Soil Sediment Contam.: Int. J. 17 (5), 533-546.

Pourrut, B., Shahid, M., Dumat, C., Winterton, P., Pinelli, E., 2011. Lead uptake, toxicity, and detoxification in plants. Rev. Environ. Contam. Toxicol. 213, $113-136$

Qiu, C., Majs, F., Eng, P.J., Stubbs, J.E., Douglas, T.A., Schmidt, M., Trainor, T.P., 2018a. In situ structural study of the surface complexation of lead (II) on the chemically mechanically polished hematite (1102) surface. J. Colloid Interface Sci. 524, 65-75.

Qiu, C., Majs, F., Douglas, T.A., Schmidt, M., Trainor, T.P., 2018b. In situ structural study of $\mathrm{Sb}(\mathrm{V})$ adsorption on hematite (1102) using X-ray surface scattering. Environ. Sci. Technol. 52 (19), 11161-11168.

Racine, C.H., Walsh, M.E., Roebuck, B.D., Collins, C.M., 1992. White phosphorus poisoning of waterfowl in an alaskan salt marsh. J. Wildl. Dis. 28 (4), 669-673.

Radar, K.J., Carbonaro, R.F., van Hullebusch, E.D., Baken, S., Delbeke, K., 2019. The fate of copper added to surface water: field, laboratory, and modeling studies. Environ. Toxicol. Chem. 38 (7), 1386-1399.

Radian, 1999a. Sampling Results for AEC Phase I Training Ordnance Emission Characterization. Radian International. Prepared for U.S. Army Dugway Proving Ground, Dugway, Utah.

Radian, 1999b. Sampling Results for AEC Phase II Training Ordnance Emission
Characterization. Radian International. Prepared for U.S. Army Dugway Proving Ground, Dugway, Utah.

Radziemska, M., Beś, A., Gusiatin, Z.M., Cerdà, A., Mazur, Z., Jeznach, J., Kowal, P. Brtnický, M., 2019. The combined effect of phytostabilization and different amendments on remediation of soils from post-military areas. Sci. Total Environ. $688,37-45$.

Randich, E., Duerfeldt, W., McLendon, W., Tobin, W., 2002. A metallurgical review of the 887 interpretation of bullet lead compositional analysis. Forensic Sci. Int $127,174-191$.

Ringelberg, D.B., Reynolds, C.M., Winfield, L.E., Inouye, L.S., Johnson, D.R. Bednar, A.J., 2009. Tungsten effects on microbial community structure and activity in soil. J. Environ. Qual. 38, 103.

Ritchie, V.J., Ilgen, A.G., Mueller, S.H., Trainor, T.P., Goldfarb, RJ. 2013. Mobility and chemical fate of antimony and arsenic in historic mining environments of the Kantishna Hills district, Denali National Park and Preserve, Alaska. Chem. Geol 335, 172-188.

Robinson, B.H., Bischofberger, S., Stoll, A., Schroer, D., Gurrer, G., Roulier, S., Gruenwald, A., Attinger, W., Schulin, R., 2008. Plant uptake of trace elements on a Swiss military shooting range: uptake pathways and land management implications. Environ. Pollut. 153, 669-676.

Rodríguez-Seijo, A., Lago-Vila, M., Arenas-Lago, D., Andrade, M.L., Vega, F.A., 2016. Pollution and risk assessment of potential hazardous elements in a shooting range soils (NW Spain). Spanish Journal of Soil Science 6, 2.

Rooney, C.P., McLaren, R.G., Cresswell, R.J., 1999. Distribution and phytoavailability of lead in a soil contaminated with lead shot. Water Air Soil Pollut. 116 (3) 535-548.

Rooney, C.P., McLaren, R.G., Condron, L.M., 2007. Control of lead solubility in soil contaminated with lead shot: effect of soil pH. Environ. Pollut. 149, 149-157.

Roscoe, D.E., Widjeskog, L., Stansley, W., 1989. Lead poisoning of northern pintai ducks feeding in a tidal meadow contaminated with shot from a trap and skeet range. Bull. Environ. Contam. Toxicol. 42, 226-233.

Rouwane, A., Rabiet, M., Grybos, M., Bernard, G., Guibaud, G., 2016. Effects of NO3(-) and $\mathrm{PO} 4(3-)$ on the release of geogenic arsenic and antimony in agricultural wetland soil: a field and laboratory approach. Environ. Sci. Pollut. Res. Int. 23 (5), 4714-4728.

Rubio, M., Mera, M.F., Pérez, C.A., Vicentin, F.C., 2017. Application of XANES spectroscopy to investigate $\mathrm{Sb}$ species in corroded bullets crust material oriented to evaluate the potential toxic effects in the environment. X Ray Spectrom. 47 (2), $171-175$.

Sanderson, P., Naidu, R., Bolan, N., Bowman, M., Mclure, S., 2012. Effect of soil type on distribution and bioaccessibility of metal contaminants in shooting range soils. Sci. Total Environ. 438, 452-462.

Sanderson, P., Naidu, R., Bolan, N., 2015. Effectiveness of chemical amendments for stabilization of lead and antimony in risk-based land management of soils of shooting ranges. Environ. Sci. Pollut. Res. 22, 8942-8956.

Scheetz, C.D., Rimstidt, J.D., 2009. Dissolution, transport, and fate of lead on a shooting range in the Jefferson National Forest near Blacksburg, VA, USA. Environ. Geol. 58 (3), 655-665.

Scheinost, A., Rossberg, A., Vantelon, D., Zifra, I., Kretzschmar, R., Leuz, A., Funke, J. Johnson, C., 2006. Quantitative antimony speciation in shooting range soils by EXAFS spectroscopy. Geochem. Cosmochim. Acta 70, 3299-3312.

Scheuhammer, A.M., 2009. Historical perspective on the hazards of environmenta lead from ammunition and fishing weights in Canada. In: Watson, R.T. Fuller, M., Pokras, M., Hunt, W.G. (Eds.), Ingestion of Lead from Spent Ammunition: Implications for Wildlife and Humans. The Peregrine Fund, Boise, Idaho, USA.

Scheuhammer, A.M., Norris, S.L., 1995. A review of the environmental impacts of lead shotshell ammunition and lead fishing weights in Canada. In: Rep. 88. Minister of Environ. Canadian Wildlife Service, Ottawa, ON.

Sehube, N., Kelebmang, R., Rotolo, O., Laetsang, M., Kamwi, O., Dinake, P., 2017. Lead pollution of shooting range soils. S. Afr. J. Chem. 70, 21-28.

Seiler, R.L., Stollenwerk, K.G., Garbarino, J.R., 2005. Factors controlling tungsten concentrations in ground water, Carson Desert, Nevada. Appl. Geochem. 20, 423.

Selim, H.M., 2012. Competitive Sorption and Transport of Heavy Metals in Soils and Geological Media Sorption. CRC Press, Florida, USA, pp. 119-145.

Sharma, A., Sachdeva, S., 2015. Cadmium toxicity and its phytoremediation A review. Int. J. Sci. Eng. Res. 6, 9.

Shtangeeva, I., Niemelä, M., Perämäki, P., 2014. Effects of soil amendments on antimony uptake by wheat. J. Soils Sediments 14, 679-686.

Sjöstedt, C., Löv, Á., Olivecrona, Z., Boye, K., Kleja, D.B., 2018. Improved geochemica modeling of lead solubility in contaminated soils by considering colloida fractions and solid phase EXAFS speciation. Appl. Geochem. 92, 110-120.

Soeder, D.J., Miller, C.V., 2003. Ground-Water Contamination from Lead Shot at Prime Hook National Wildlife Refuge, Sussex County, Delaware, vols. 2-4282. US Geological Survey, Water-Resources Investigation Report, Baltimore, MD.

Sorvari, J., Antikainen, R., Pyy, O., 2006. Environmental contamination at Finnish shooting ranges - the scope of the problem and management options. Sci. Total Environ. 366, 21-31.

Stansley, W., Widjeskog, L., Roscoe, D.E., 1992. Lead contamination and mobility in surface water at trap and skeet ranges. Bull. Environ. Contam. Toxicol. 49, 640-647.

Strigul, N., Koutsospyros, A., Arienti, P., Christodoulatos, C., Dermatas, D., Braida, W., 2005. Effects of tungsten on environmental systems. Chemosphere 61, 248.

Strømseng, A.E., Ljones, M., Bakka, L., Mariussen, E., 2009. Episodic discharge of lead 
copper and antimony from a Norwegian small arm shooting range. J. Environ. Monit. 11 (6), 1259-1267.

Sunahara, G.I., Lotufo, G., Kuperman, R.G., Hawai, J., 2009. Ecotoxicology of Explosives. CRC Press, Boca Raton, FL.

Tandy, S., Meier, N., Schulin, R., 2017. Use of soil amendments to immobilize antimony and lead in moderately contaminated shooting range soils. J. Hazard Mater. 324, 617-625.

Thiboutot, S., Ampleman, G., Martel, R., Lefebvre, R., Paradis, D., 2001. Environmental Charaterisation of Canadian Forces Base Shilo Training Area (Battleruns) Following GATES Closure. Technical Report DREV TR 2001-126. Defense Research Establishment Valcartier. Valcartier, Quebec, Canada.

Thiboutot, S., Ampleman, G., Lewis, J., Faucher, D., Marois, A., Martel, R., Ballard, J.M., Downe, S., Jenkins, T.F., Hewitt, A., 2003a. Environmental Conditions of Surface Soils and Biomass Prevailing in the Training Area at CFB Gagetown, New Brunswick. DREV-TR-2003-152. Defense Research Establishment Department of National Defense, Valcartier, Quebec, Canada.

Thiboutot, S., Ampleman, G., Hamel, A., Ballard, J.M., Martel, R., Others, 2003b. Research on the Environmental Conditions of Ground and Surface Water Prevailing in the Training Area of CFB Gagetown. Valcartier-TR-2003-016. Defense Research Establishment Department of National Defense, Valcartier, Quebec, Canada.

Thiboutot, S., Ampleman, G., Brochu, S., Poulin, I., Marois, A., Gagnon, A., 2012. Guidance document: surface soils sampling for munitions residues in military live fire training ranges: Canadian protocol. Technical Report DRDC Valcartier TR 2011-447 1-108.

Tighe, M., Lockwood, P., Wilson, S., 2005. Adsorption of antimony (V) by floodplain soils, amorphous iron (III) hydroxide and humic acid. J. Environ. Monit. 7, 1177-1185.
U.S. Army Corps of Engineers, 2015. Technical guidance for military munitions response actions. Engineer Manual 30.

U.S. Geological Survey, 2013. Mineral industry surveys: lead in January. Accessed. http://minerals.usgs.gov/minerals/pubs/commodity/lead/mis-201301-lead.pdf. (Accessed 23 October 2016).

VanDeMark, T.F., Johnson, L.B., Pitarka, A., Bennett Jr., H.H., Simms, J.E., Yule, D.E., 2013. Evaluation of seismic-acoustic analysis methods for real-time UXO monitoring system. J. Environ. Eng. Geophys. 18 (1), 71-85.

Vantelon, D., Lanzirotti, A., Scheinost, A.C., Kretzschmar, R., 2005. Spatial distribution and speciation of lead around corroding bullets in a shooting range soil studied by micro-X-ray fluorescence and absorption spectroscopy. Environ. Sci. Technol. 39, 4808-4815.

WHO, World Health Organization, 2003. Antimony in Drinking Water; Background Document for Development of WHO Guidelines for Drinking Water Quality. World Health Organization.

Wilson, S.C., Lockwood, P.V., Ashley, P.M., Tighe, M., 2010. The chemistry and behavior of antimony in the soil environment with comparisons to arsenic: a critical review. Environ. Pollut. 158 (5), 1169-1181.

Wynter, M., Larson, S.L., Martin, W.A., Griggs, C.S., O'Connor, G., Mackie, D. Nestler, C.C., 2012. Passive Reactive Berm to Provide Low Maintenance Lead Containment at Active Small Arms Firing Ranges. ERDC-EL TR-12-20. U.S. Army Engineer Research and Development Center, Environmental Laboratory, Vicksburg, MS.

Yang, H., He, M., 2016. Distribution and speciation of selenium, antimony, and arsenic in soils and sediments around the area of Xikuangshan (China). Soil Air Water 44 (11), 1538-1546.

Yin, X., Gao, B., Ma, L.Q., Saha, U.K., Sun, H., Wang, G., 2010. Colloid-facilitated Pb transport in two shooting-range soils in Florida. J. Hazard Mater. 177, 1-3. 


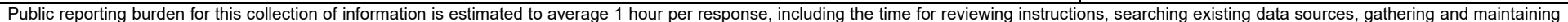

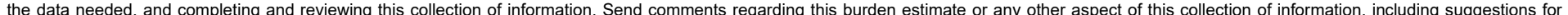

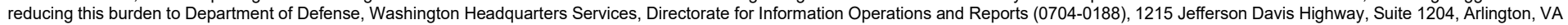

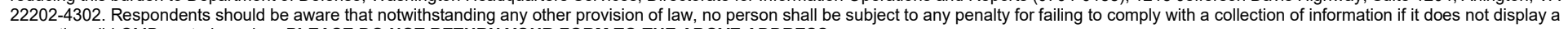
currently valid OMB control number. PLEASE DO NOT RETURN YOUR FORM TO THE ABOVE ADDRESS.
1. REPORT DATE
February 2022

\section{TITLE AND SUBTITLE}

Environmental Impact of Metals Resulting from Military Training Activities:

A Review

\section{AUTHOR(S)}

Amanda J. Barker, Jay L. Clausen, Thomas A. Douglas, Anthony J. Bednar, Christopher S. Griggs, William A. Martin

\section{PERFORMING ORGANIZATION NAME(S) AND ADDRESS(ES)}

See next page.

National Guard Bureau

Impact Area GW Study Office

Camp Edwards, MA 02452

\section{DATES COVERED (From - To)}

5a. CONTRACT NUMBER

5b. GRANT NUMBER

5c. PROGRAM ELEMENT NUMBER

5d. PROJECT NUMBER

5e. TASK NUMBER

\section{5f. WORK UNIT NUMBER}

8. PERFORMING ORGANIZATION REPORT NUMBER

ERDC MP-22-2

10. SPONSOR/MONITOR'S ACRONYM(S)

11. SPONSOR/MONITOR'S REPORT NUMBER(S)

\section{DISTRIBUTION / AVAILABILITY STATEMENT}

Approved for public release; distribution is unlimited.

\section{SUPPLEMENTARY NOTES}

This article was originally published online in Chemosphere on 26 November 2020.

Funding was provided by the National Guard Bureau at Camp Edwards, MA under MIPR 90353118.

\section{ABSTRACT}

The deposition of metals into the environment as a result of military training activities remains a longterm concern for Defense organizations across the globe. Of particular concern for deposition and potential mobilization are antimony (Sb), arsenic (As), copper $(\mathrm{Cu})$, lead $(\mathrm{Pb})$, and tungsten $(\mathrm{W})$, which are the focus of this review article. The fate, transport, and mobilization of these metals are complicated and depend on a variety of environmental factors that are often convoluted, heterogeneous, and site dependent.

While there have been many studies investigating contaminant mobilization on military training lands there exists a lack of cohesiveness surrounding the current state of knowledge for these five metals. The focus of this review article is to compile the current knowledge of the fate, transport, and ultimate risks presented by metals associated with different military training activities particularly as a result of small arms training activities, artillery/mortar ranges, battleruns, rocket ranges, and grenade courts. From there, we discuss emerging research results and finish with suggestions of where future research efforts and training range designs could be focused toward further reducing the deposition, limiting the migration, and decreasing risks presented by metals in the environment. Additionally, information presented here may offer insights into $\mathrm{Sb}, \mathrm{As}, \mathrm{Cu}, \mathrm{Pb}$, and $\mathrm{W}$ in other environmental settings.

\section{SUBJECT TERMS}

Metals; Shooting ranges; Lead; Antimony; Tungsten; Fate and transport

\section{SECURITY CLASSIFICATION OF:}

\section{a. REPORT}

Unclassified

\section{b. ABSTRACT}

Unclassified c. THIS PAGE

Unclassified
17. LIMITATION OF ABSTRACT

UU
18. NUMBER OF PAGES 19a. NAME OF RESPONSIBLE PERSON

19b. TELEPHONE NUMBER (include area code) 
7. PERFORMING ORGANIZATION NAME(S) AND ADDRESS(ES)

Cold Regions Research and Engineering Laboratory U.S. Army Engineer Research and Development Center Fort Wainwright, AK $99703 \quad 72$ Lyme Road, Hanover, NH 03755

\section{Environmental Laboratory}

U.S. Army Engineer Research and Development Center 3909 Halls Ferry Road

Vicksburg, MS 39180 